\title{
Efficient photocatalytic degradation of organic dyes using FexZn1-xO nanoparticles
}

senthil kumar ( $\square$ msenkumar21@gmail.com )

Srinivasan College of Arts and Science https://orcid.org/0000-0002-5330-0790

C. Arunagiri

Periyar EVR College

\section{Research Article}

Keywords: Visible light, Photocatalytic degradation, ZnO, Doping

Posted Date: March 29th, 2021

DOl: https://doi.org/10.21203/rs.3.rs-314486/v1

License: (9) This work is licensed under a Creative Commons Attribution 4.0 International License. Read Full License 


\title{
Efficient photocatalytic degradation of organic dyes using $\mathrm{Fe}_{\mathrm{x}} \mathrm{Zn}_{1-\mathrm{x}} \mathrm{O}$ nanoparticles
}

\author{
M. Senthilkumar ${ }^{1}$, C. Arunagiri ${ }^{2 \#^{* *}}$ \\ ${ }^{1}$ Department of Physics, Srinivasan College of Arts and Science, Perambalur - 621 212, India \\ ${ }^{2}$ PG\& Research Department of Physics, Periyar EVR College, Tiruchirappalli - 620 023, India \\ ${ }^{\#}$ Affiliated to Bharathidasan University, Tiruchirappalli - 620 023, India
}

\begin{abstract}
$\mathrm{Fe}_{\mathrm{x}} \mathrm{Zn}_{1-\mathrm{x}} \mathrm{O}(\mathrm{x}=0,0.05,0.075$, and $0.1 \mathrm{M})$ nanoparticles based photocatalysts are successfully synthesized by co-precipitation method. The synthesized nanoparticles are characterized using X-ray diffraction (XRD), scanning electron microscopy (SEM) with energydispersive X-ray spectroscopy (EDX), and UV-visible double beam spectroscopy (UV-Vis) techniques. The prepared catalysts and its photocatalytic activity was evaluated by methylene blue (MB) and methyl orange (MO) dye under visible light irradiation. The effect of various photocatalyst parameters such as $\mathrm{pH}$, catalyst dosage, and initial dye concentration on the photodegradation was examined in detail.
\end{abstract}

Keywords: Visible light, Photocatalytic degradation, ZnO, Doping.

Corresponding Author: *arunasuba03@gmail.com

\section{INTRODUCTION}

In recent years, many hazardous organic pollutants, such as toxic dyes and organic residuals released into the atmosphere from several industries [1, 2]. The degradation and fullmineralization process are vicious, because of merged structure of organic dyes. Among these organic dyes, methylene blue (MB: $\left.\mathrm{C}_{16} \mathrm{H}_{18} \mathrm{~N}_{3} \mathrm{SCl}\right)$ and methyl orange (MO: $\mathrm{C}_{14} \mathrm{H}_{14} \mathrm{~N}_{3} \mathrm{NaO}_{3} \mathrm{~S}$ ) are highly harmful to the atmosphere, which then poses a threat to the health of humans and animals [3]. Industrial wastewater treatment and recycling are fundamental objectives to secure the worldwide biological system and improve the environment's quality. Various techniques have been extensively utilized to suppress pollutants from contaminated water sources $[4,5]$. Among them, photocatalysis has emerged to be a promising way to control the massive scale's current environmental pollution. The photocatalysts with semiconducting nanostructures have concerned much more attention due to their exceptional physico-chemical properties in the photocatalytic reaction [6-8]. 
Many researchers recently developed many photocatalysts using metal oxide semiconductor nanoparticles, including $\mathrm{Bi}_{2} \mathrm{O}_{3}, \mathrm{TiO}_{2}, \mathrm{ZnO}$, and $\mathrm{WO}_{3}$. Among these transition metal oxides, zinc oxide $(\mathrm{ZnO})$ is found very sensible in the photocatalytic method due to their wide-bandgap, non-toxicity, and high photosensitivity [9-11]. $\mathrm{ZnO}$ is a wide-bandgap semiconductor with a direct energy bandgap $(\mathrm{Eg} \approx 3.37 \mathrm{eV})[12,13]$. $\mathrm{ZnO}$ nanoparticles are especially attractive for many interesting nanotechnology applications such as transparent conductive coatings [14], photoanodes for dye-sensitized solar cells (DSSCs) [15], gas sensors [16], and electro-photo luminescent materials [17]. Unfortunately, ZnO can only absorb UV light [18], and photocatalytic degradation efficiency was confined by the electron-hole charge carriers, low-adsorption, and low-reusability. Rectify this problem, numerous reports focused on doping $\mathrm{ZnO}$ with transition metal (Fe, Co, Mn) ions [19], non-metal (N, C, S) ions [20], and noble metals loading (Ag, Au, Pd) [21] have been carried out. Various techniques for the synthesis $\mathrm{ZnO}$ and Fe-doped $\mathrm{ZnO}$ nanoparticles are reported in the literature: hydrothermal method [22], combustion [23], and sol-gel method [24]. Among these synthesis methods, co-precipitation [25] is a flexible method for synthesizing the $\mathrm{ZnO}$ nanoparticles due to its low-cost, and easy to operate.

Several studies have been reported that the doping of $\mathrm{ZnO}$ with transition metal ions for visible light photocatalysts [26, 27]. It has been discovered that 2\% Fe-doped $\mathrm{ZnO}$ nanoparticles degraded the methyl orange dye up to $80.8 \%$ within 210 mins under sunlight irradiation. The Fe doped $\mathrm{ZnO}$ degrades $\mathrm{MB}$ in $4 \mathrm{~h}$ in sunlight [28]. Zhang et al. investigated that $\mathrm{Fe} / \mathrm{ZnO}$ nanowires' utilization is superior to P25 against MO [29]. Abbad et al. synthesized a Fe-doped $\mathrm{ZnO}$ nanoparticle and degraded 2-chlorophenol under solar irradiation. The most significant photocatalytic action was accomplished with the optimized dopant centralization of $0.5 \mathrm{wt} \% \mathrm{Fe}$ because of the small crystallite size and low bandgap with a low oxidation-reduction potential [30].

In the present work, we reported the various properties of an efficient Fe-doped $\mathrm{ZnO}$ nanoparticles for photocatalytic reaction. The effect various dopant concentration on structural, morphological, optical, and electrical properties of $\mathrm{ZnO}$ nanoparticles was investigated. Furthermore, we investigated the photocatalytic degradation of MB and MO dye under UV light irradiation. 


\section{EXPERIMENTAL}

\subsection{Preparation}

Fe-doped $\mathrm{ZnO}\left(\mathrm{Fe}_{\mathrm{x}} \mathrm{Zn}_{1-\mathrm{x}} \mathrm{O}\right)$ nanoparticles were synthesized using various mol.\% $(\mathrm{x} \approx 0$, $0.05,0.075$, and 0.1 ) of nanoparticles using co-precipitation method. The chemicals such as zinc nitrate hexahydrate $\left[\mathrm{Zn}\left(\mathrm{NO}_{3}\right)_{2} .6 \mathrm{H}_{2} \mathrm{O}\right]$, ferric nitrate nonahydrate $\left[\mathrm{Fe}\left(\mathrm{NO}_{3}\right)_{2} .9 \mathrm{H}_{2} \mathrm{O}\right]$ and sodium hydroxide $[\mathrm{NaOH}]$ used in the present study are of analytical grade obtained from Alfa Aesar chemicals, India.

To synthesis pure $\mathrm{ZnO}$ nanoparticles, $10 \mathrm{~g}$ of $\mathrm{Zn}\left(\mathrm{NO}_{3}\right)_{2} \cdot 6 \mathrm{H}_{2} \mathrm{O}$ was dissolved into $20 \mathrm{~mL}$ of deionized water (DW) and in parallel $8 \mathrm{~g}$ of $\mathrm{NaOH}$ was added drop wise in $100 \mathrm{~mL}$ water under continuous stirring until to reach $\mathrm{pH}=11$. Then the above solution was heated in in a vacuum oven at $100{ }^{\circ} \mathrm{C}$ for $2 \mathrm{~h}$. The obtained precipitates were centrifuged, washed three times with DW and ethanol; finally it was dried at $100{ }^{\circ} \mathrm{C}$ for $4 \mathrm{~h}$. The collected precipitates were calcined at $450{ }^{\circ} \mathrm{C}$ for $1 \mathrm{~h}$. To synthesis, various concentrations of Fe-doped $\mathrm{ZnO}$ nanoparticles, such as $\mathrm{Fe}=0.05,0.075$, and $0.1 \mathrm{~mol} \%, 0.68$ to $3.4 \mathrm{~g}$ of $\mathrm{Fe}\left(\mathrm{NO}_{3}\right)_{2} .9 \mathrm{H}_{2} \mathrm{O}$ was added into the reaction mixture.

\subsection{Characterization Techniques}

XRD patterns of the samples were recorded using a mini desktop X-ray diffractometer (X'PERT PRO MPD) operated at an accelerating potential of $40 \mathrm{kV}$ and $30 \mathrm{~mA}$ filament current with $\mathrm{CuK} \alpha$ radiation of wavelength $1.5406 \AA$ with a scanning rate of $3 / \mathrm{min}$. (from $2 \theta=10$ to 80 $\left.{ }^{\circ} \mathrm{C}\right)$. The surface morphology and particles size of the samples were characterized by scanning electron microscope (SEM-JEOL JS-6390) with energy dispersive X-ray spectrometer (EDS). UV-visible absorbance spectra of the samples were measured with a Systronics: AU-2707 double-beam spectrophotometer in the absorption range 190-1000 nm. Fourier transform infrared (FT-IR) spectra of the samples were analyzed by JASCO FTIR-410 spectrometer in the range 400-4000 $\mathrm{cm}^{-1}$. The current-voltage (I-V) characteristic curves were recorded using the Keithley electrometer 2400 model. 


\subsection{Photocatalytic degradation test}

The photocatalytic activity of the samples was evaluated by the degradation of $\mathrm{MB}$ and MO under UV light irradiation (8 W Philips). $20 \mathrm{mg}$ of $\mathrm{Fe}_{\mathrm{x}} \mathrm{Zn}_{1-\mathrm{x}} \mathrm{O}$ photocatalysts were dissolved in $20 \mathrm{~mL}$ aqueous $\mathrm{MB}$ and $\mathrm{MO}$ dye solution at various $\mathrm{pH}(2,4$, and 6). The dye solutions with $\mathrm{Fe}_{\mathrm{x}} \mathrm{Zn}_{1-\mathrm{x}} \mathrm{O}$ photocatalysts were exposed to UV light from 0 to $180 \mathrm{~min}$. at room temperature. Every 30 minutes, sampling out $2 \mathrm{ml}$ of dye solution collected from samples for photocatalytic degradation test. The photocatalytic degradation of MB and MO was observed $\lambda_{\max }$ at $\sim 664$ and $464 \mathrm{~nm}$ respectively using a UV-visible spectrophotometer in the wavelength range $200-800 \mathrm{~nm}$.

\section{Results and discussion}

\subsection{X-ray diffraction (XRD)}

Fig. 1(a) shows the powder XRD characteristic patterns of $\mathrm{Fe}_{\mathrm{x}} \mathrm{Zn}_{1-\mathrm{x}} \mathrm{O}(\mathrm{x} \approx 0,0.05,0.075$, $0.1 \%$ ) nanoparticles. All the XRD diffraction peaks are indexed to the hexagonal wurtzite structure of crystalline $\mathrm{ZnO}$, further confirmed from the standard JCPDS No. 36-1451 ( $\mathrm{a}=0.325$ $\mathrm{nm}$ and $\mathrm{c}=0.5207 \mathrm{~nm}$ ) [31-32]. There are no characteristic peaks of Fe phases, or its oxides were not detected in the samples. Fig. 1(b) revealed that the magnification of primary peak at 31.8 (100), $34.3(002)$, and $36.3^{\circ}$ (101), it shows a minor shift in the $0.05,0.075$, and $0.1 \% \mathrm{Fe}-$ doped $\mathrm{ZnO}$. The ionic radii of $\mathrm{Fe}^{3+}$ and $\mathrm{Zn}^{2+}$ are different $\left(\mathrm{Fe}^{3+}=0.68 \AA\right.$ and $\mathrm{Zn}^{2+}=0.74 \AA$ ). This result suggests that the $\mathrm{Fe}$ ions substitute into the $\mathrm{ZnO}$ lattice [33]. The average crystallite sizes (D) of the Fex $\mathrm{Zn}_{1-\mathrm{x}} \mathrm{O}$ was determined from the Debye-Scherrer equation (Eq. 1) [34].

$$
\mathrm{D}=0.9 \lambda / \beta \cos \theta
$$

Where $\lambda$ is the incident of diffraction angle, $\beta$ is the full width half maximum of the peak (FWHM), $\theta$ is the wavelength of the X-rays (1.5406 $\AA$ ), respectively. The lattice parameters and average crystalline size of the samples are listed in Table 1. The average crystallite size (D) of $\mathrm{Fe}_{\mathrm{x}} \mathrm{Zn}_{1-\mathrm{x}} \mathrm{O}$ calculated from XRD data are 23.5, 21.6, 16.2 and $12 \mathrm{~nm}$, respectively. Furthermore, the increasing Fe content reduces the lattice parameters and average crystallite size. Previous reports reported by Jayachitra et al. [35] in Fe-doped ZnO nanoparticles, Srinivasan et al. [36] in Mn-doped $\mathrm{ZnO}$ and $\mathrm{Nahm}$ et al. [37] in $\mathrm{V}_{2} \mathrm{O}_{5}$ doped $\mathrm{ZnO}$ ceramics are also similar to the obtained results. 
Table 1. The lattice parameters and average crystallite size of $\mathrm{Fe}_{\mathrm{x}} \mathrm{Zn}_{1-\mathrm{x}} \mathrm{O}$ nanoparticles.

\begin{tabular}{cccccc}
\hline $\begin{array}{c}\text { Fe Doping } \\
\text { Concentration } \\
(\mathbf{m o l . \% )}\end{array}$ & hkl & $\begin{array}{c}\mathbf{2 \theta} \\
(\mathbf{d e g r e e})\end{array}$ & $\mathbf{a}[\AA \mathbf{A}]$ & $\mathbf{c}[\AA]$ & $\begin{array}{c}\text { Crystallite } \\
\text { size (nm) }\end{array}$ \\
\hline $\mathrm{ZnO}$ & $(100)$ & 31.77 & & & \\
& $(002)$ & 34.40 & 3.24 & 5.20 & 23.53 \\
& $(101)$ & 36.30 & & & \\
$\mathrm{Fe}_{0.05} \mathrm{Zn}_{0.95} \mathrm{O}$ & $(100)$ & 31.81 & & & \\
& $(1002)$ & 34.23 & 3.25 & 5.21 & \\
& $(101)$ & 36.37 & & & \\
$\mathrm{Fe}_{0.075} \mathrm{Zn}_{0.925 \mathrm{O}}$ & $(002)$ & 34.43 & 3.25 & 5.20 & \\
& $(101)$ & 36.17 & & & \\
& $(100)$ & 31.81 & & & \\
$\mathrm{Fe}_{0.1} \mathrm{Zn}_{0.9} \mathrm{O}$ & $(002)$ & 34.23 & 3.24 & 5.20 & \\
& $(101)$ & 36.23 & & & \\
\hline
\end{tabular}

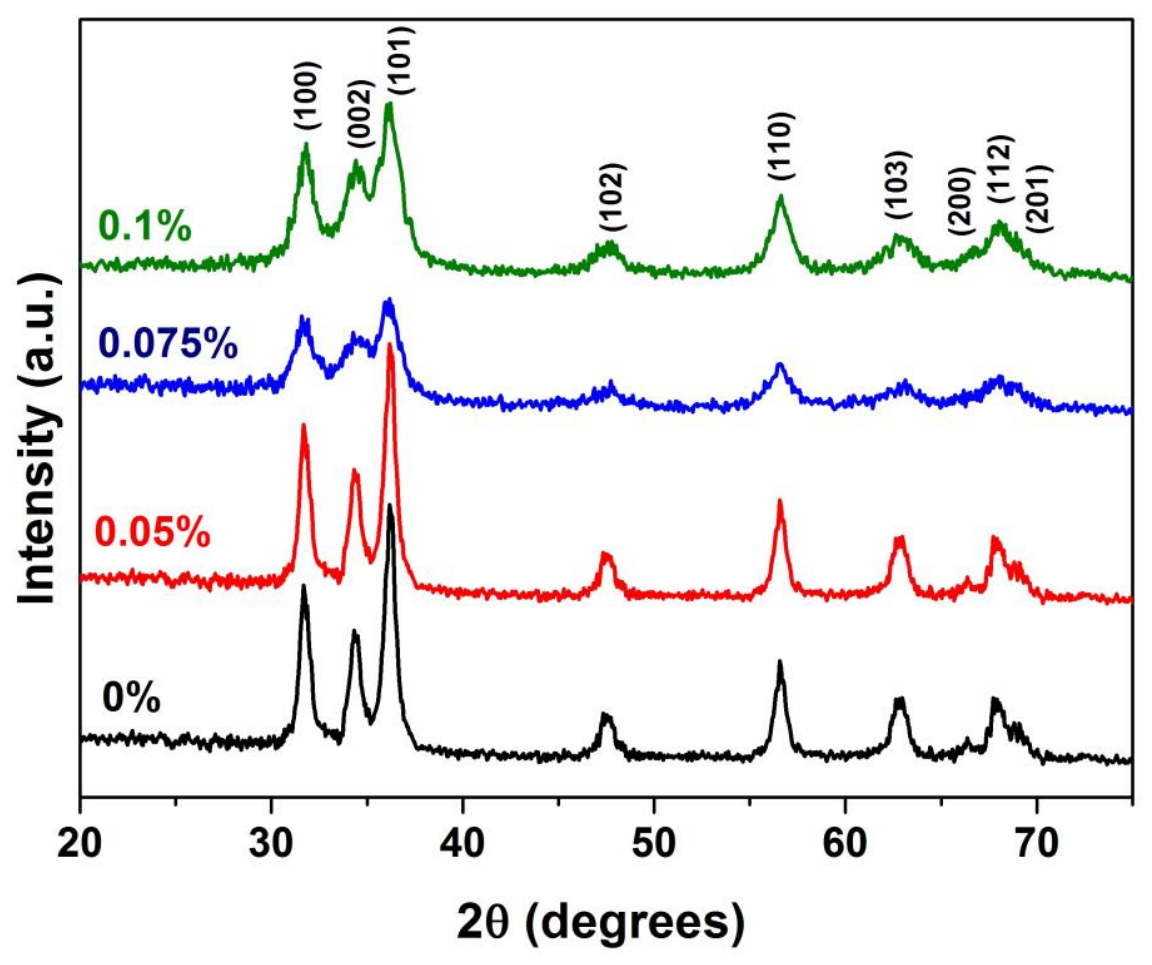




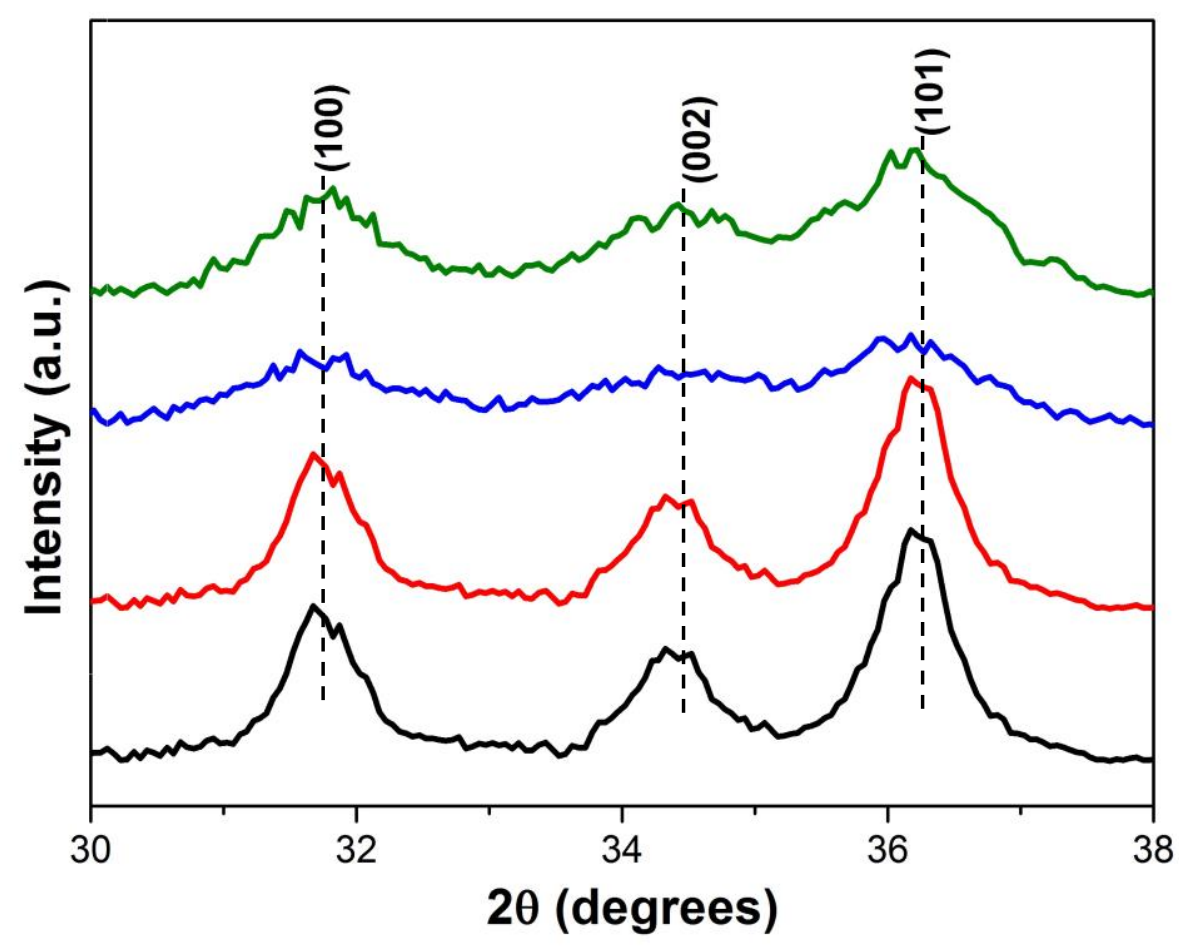

Fig. 1(a) XRD patterns of (a) undoped $\mathrm{ZnO}$ and Fe-doped $\mathrm{ZnO}(0.05,0.075 \& 0.1 \mathrm{~mol} . \%)$ nanoparticles (b) Fe concentration dependent shift in primary diffraction peaks.

\subsection{SEM Analysis}

The surface morphologies of $\mathrm{Fe}_{\mathrm{x}} \mathrm{Zn}_{1-\mathrm{x}} \mathrm{O}(\mathrm{x} \approx 0,0.05,0.075$, and $0.1 \mathrm{~mol} . \%)$ nanoparticles are shown in Fig. 2(a-d). Fig. 2(a) shows the irregular structure morphology of the undoped $\mathrm{ZnO}$, having crystallite size about $\sim 42-68 \mathrm{~nm}$. Interestingly, when the $\mathrm{Fe}$ concentration was 0.05 mol.\%, the $\mathrm{ZnO}$ nanoparticles are turned into irregular pore like structure [Fig. 2(b)]. Fig. 2(c-d) shows turning of needle and spherical like structures due to the doping of 0.075 to $0.1 \mathrm{~mol} \% \mathrm{Fe}$ dopants in $\mathrm{ZnO}$ nanoparticles. Compared with undoped $\mathrm{ZnO}, 0.1$ mol.\% of Fe-doped $\mathrm{ZnO}$ showed more information on the surface. The images clearly exposed that the surface morphology changed with the addition of Fe concentration, the agglomerated particles breaks and pores were created and then finally reduced into spherical nanoparticles. It can also be noticed that the size and morphology of $\mathrm{Fe}_{\mathrm{x}} \mathrm{Zn}_{1-\mathrm{x}} \mathrm{O}$ nanoparticles enhanced with the dopant concentration. 

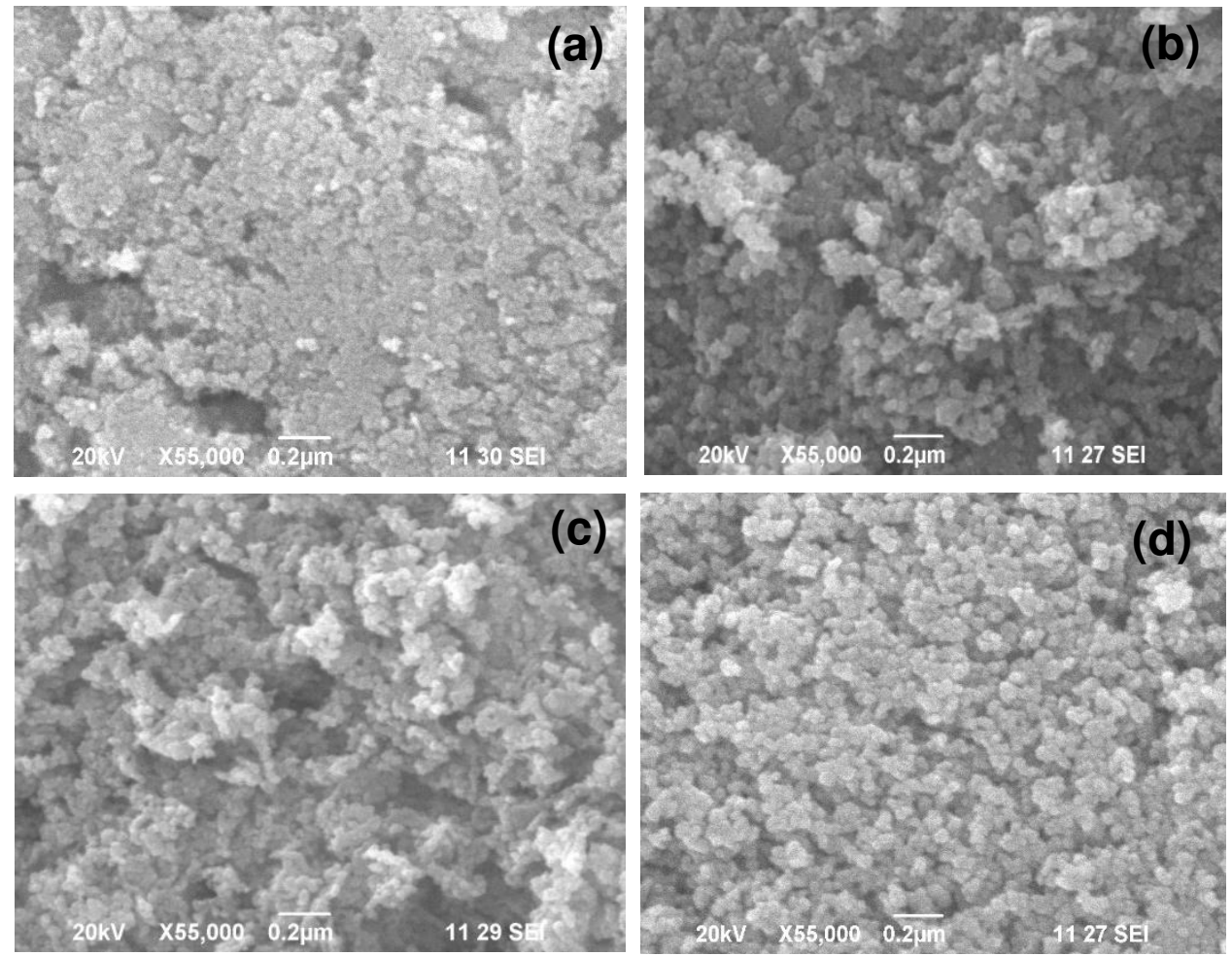

Fig. 2 SEM images of (a) undoped $\mathrm{ZnO}$ (b) 0.05, (c) 0.075 and (d) 0.1 mol.\% Fe-doped ZnO nanoparticles

\subsection{EDX Analysis}

EDX analysis (Fig. 3a-d) was used to investigate the chemical composition of $\mathrm{Fe}_{\mathrm{x}} \mathrm{Zn}_{1-\mathrm{x}} \mathrm{O}$ $(\mathrm{x} \approx 0,0.05,0.075$ and $0.1 \mathrm{~mol} \%)$ nanoparticles. EDX spectrum of undoped $\mathrm{ZnO}$ shows the existence of characteristic peaks of oxygen $(\mathrm{O})$ and zinc $(\mathrm{Zn})$ elements (Fig. 3a). The atomic percentage of these elements found to be 49.5 and 50.5\%, respectively. Fig. 3(b-d) shows the EDX spectra of Fe-doped $\mathrm{ZnO}$ nanoparticles also include elements such as $\mathrm{O}, \mathrm{Zn}$ and Fe, respectively. The inset of EDX image $\mathrm{Fe}_{\mathrm{x}} \mathrm{Zn}_{1-\mathrm{x}} \mathrm{O}$ nanoparticles data was given in table format. The measured Fe concentration of $0.05,0.075$ and 0.1 mol.\%, are about 2.71, 14.94, and 18.21\% respectively. The observed atomic percentage values almost match well with the samples. 

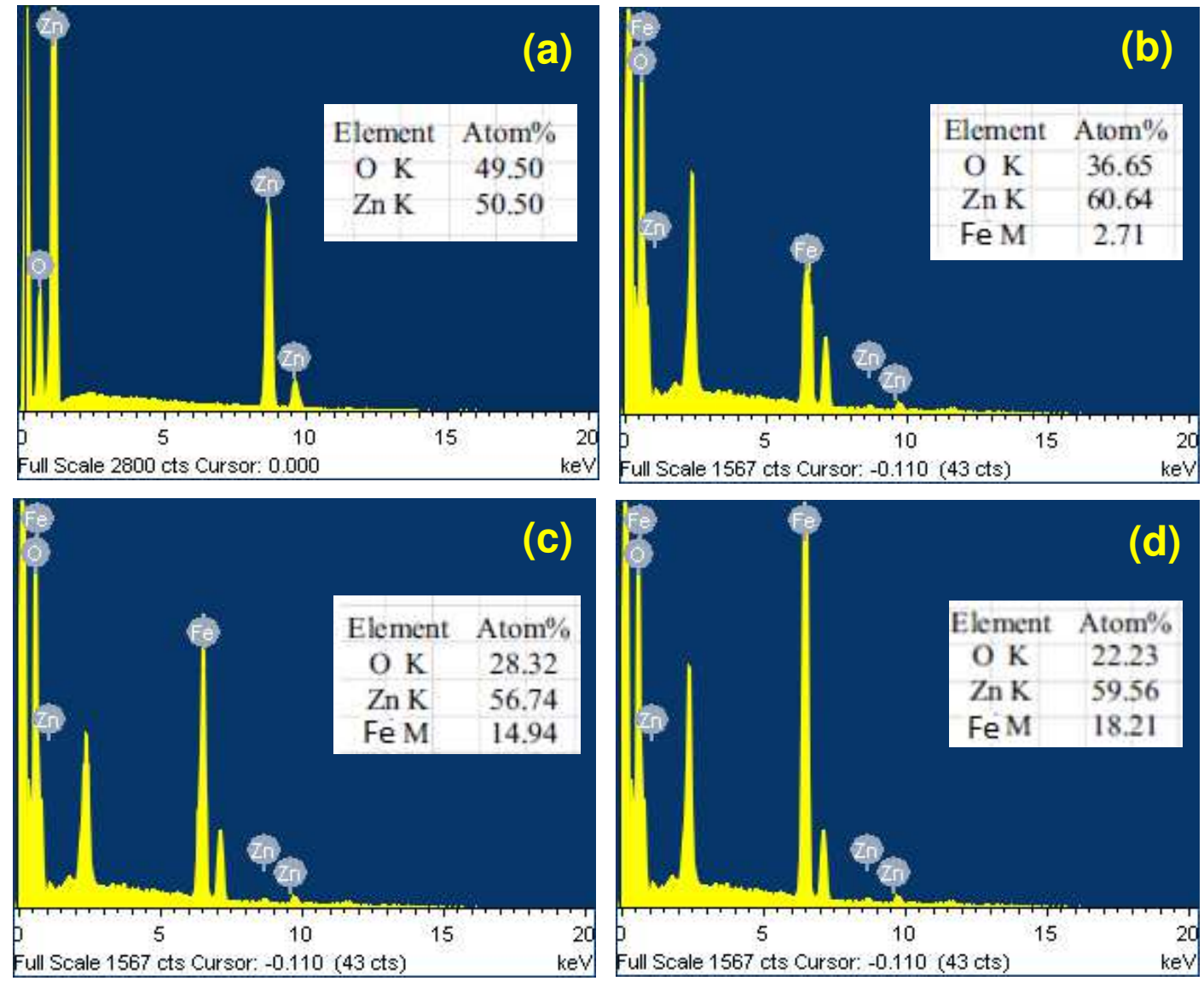

Fig. 3 EDS images of (a) undoped $\mathrm{ZnO}$ (b) 0.05 , (c) 0.075 and (d) 0.1 mol.\% Fe-doped

\section{ZnO nanoparticles}

\subsection{UV-Vis spectral studies}

UV-absorption spectra of $\mathrm{Fe}_{\mathrm{x}} \mathrm{Zn}_{1-\mathrm{x}} \mathrm{O}(\mathrm{x} \approx 0,0.05,0.075 \& 0.1 \mathrm{~mol} . \%)$ nanoparticles are shown in Fig. 4 (a-d). The absorption edge is shifted towards a higher wavelength region, which means that the band gap decreases. The red-shift is due to the increase of crystallite size, and it was confirmed from the XRD results. The optical band gap of $\mathrm{ZnO}$ and $\mathrm{Fe}$-doped $\mathrm{ZnO}$ nanoparticles was calculated using the formula $\mathrm{Eg}=\mathrm{hc} / \lambda$ [38-40]. The calculated optical bandgap values are 3.90, 3.89, 3.86 and $3.82 \mathrm{eV}$, which corresponds to undoped $\mathrm{ZnO}$ and 0.05, $0.075 \& 0.1 \mathrm{~mol}$ \% Fe-doped $\mathrm{ZnO}$ nanoparticles. Similar result was also observed by Hassan $e t$ al. [41]. The substitute of $\mathrm{Fe}^{3+}$ with $\mathrm{Zn}^{2+}$ ion shares the oxygen with $\mathrm{Zn}$ atoms and reduces the band gap. 


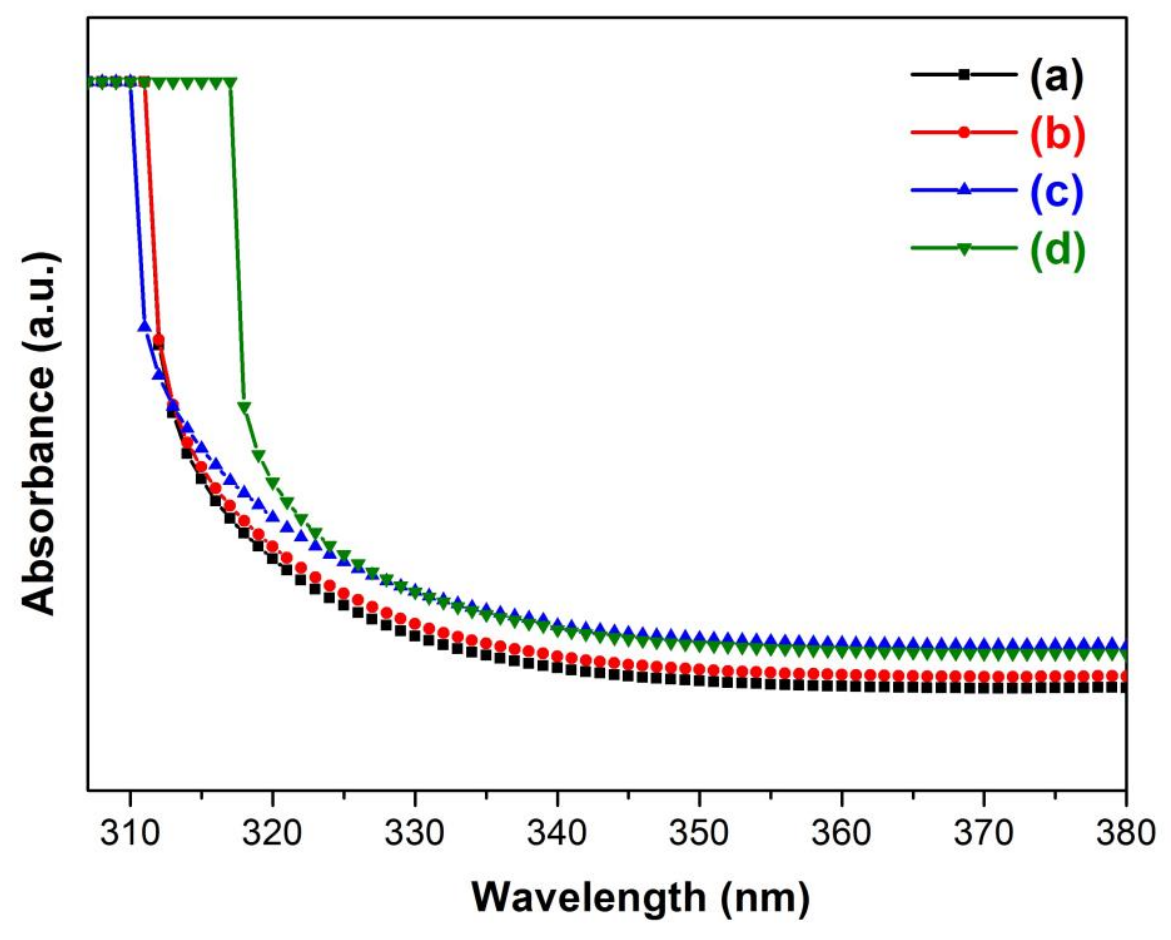

Fig. 4 UV-Vis absorbance spectra of (a) undoped $\mathrm{ZnO}$ (b) 0.05 , (c) 0.075 and (d) $0.1 \mathrm{~mol} . \%$ Fe-doped ZnO nanoparticles

\subsection{FTIR Analysis}

FTIR spectra of $\mathrm{Fe}_{\mathrm{x}} \mathrm{Zn}_{1-\mathrm{x}} \mathrm{O}(\mathrm{x} \approx 0$ and $0.1 \mathrm{~mol} \%$ ) nanoparticles in the range $4000-400$ $\mathrm{cm}^{-1}$ are presented in Fig. $5(\mathrm{a}, \mathrm{b})$. The broad absorption band appearing in the range 3452-3446 $\mathrm{cm}^{-1}$ corresponds to $-\mathrm{OH}$ stretching vibration, while the two peaks located at 1625 and $1591 \mathrm{~cm}^{-1}$ is due to $-\mathrm{OH}$ bending vibration of the adsorbed $\mathrm{H}_{2} \mathrm{O}$ molecules [42]. The band lower intensity absorbed around $2380 \mathrm{~cm}^{-1}$ which corresponds to the symmetric and asymmetric $\mathrm{C}-\mathrm{H}$ bond. Two weak absorption peaks at 428 and $449 \mathrm{~cm}^{-1}$ for undoped and $0.1 \mathrm{~mol} \%$ Fe-doped $\mathrm{ZnO}$ sample may corresponds to $\mathrm{Zn}-\mathrm{O}$ stretching mode. The absorption peaks located at 1120, 1122, and 800 $\mathrm{cm}^{-1}$ attributed to the sulfate group, respectively [43]. Also, FTIR spectra of $0.1 \mathrm{~mol} \%$ Fe-doped 
$\mathrm{ZnO}$ shows that the small stretch observed at $601 \mathrm{~cm}^{-1}$ corresponds to $\mathrm{Fe}-\mathrm{O}$ stretch, as reported by Liu et al. [43]. Therefore, it might be due to $\mathrm{Fe}^{3+}$ ions substituted in $\mathrm{Zn}$.

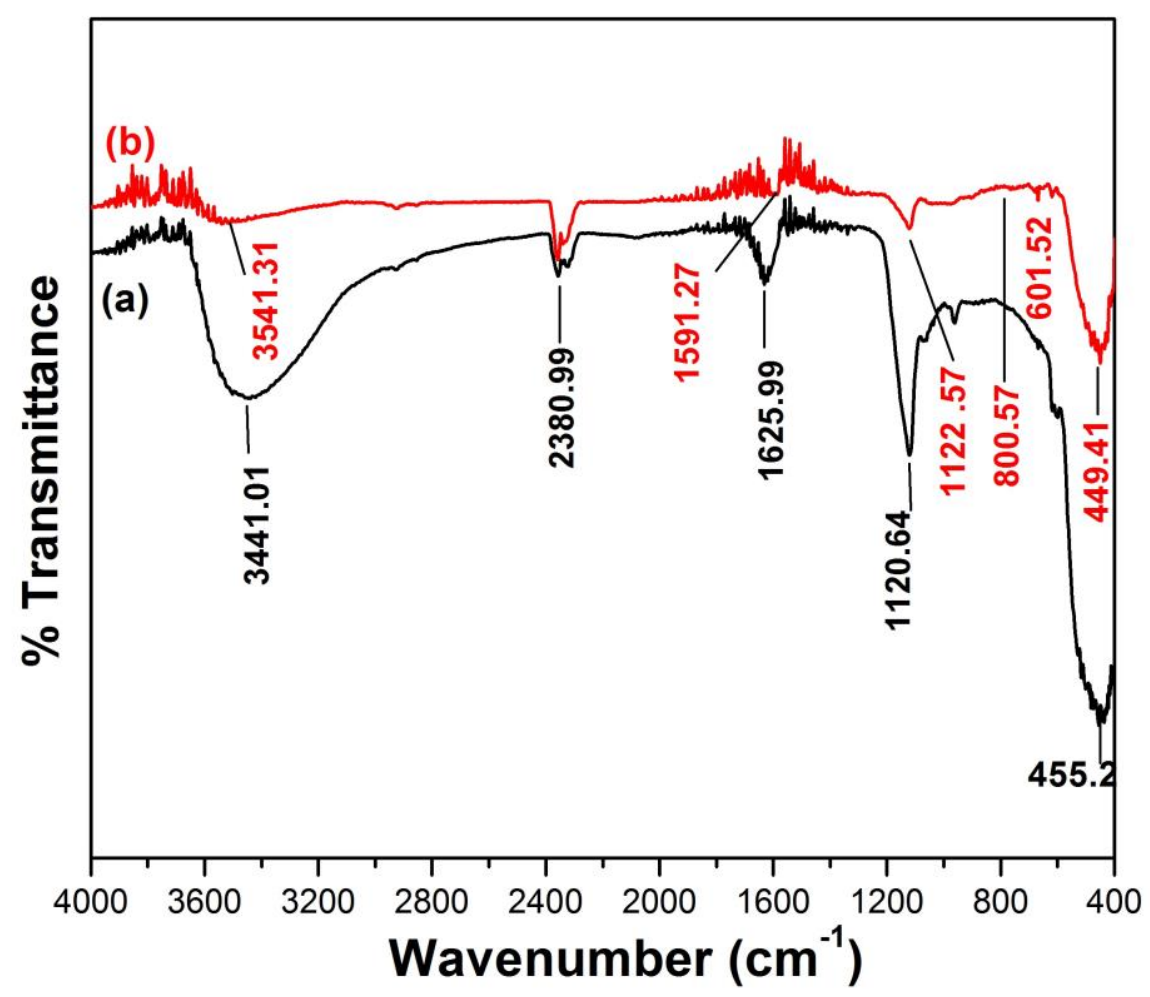

Fig. 5 FT-IR spectra of (a) undoped ZnO and (b) 0.1 mol.\% Fe-doped ZnO nanoparticles

\subsection{I-V Characteristics}

The I-V characteristics of $\mathrm{Fe}_{\mathrm{x}} \mathrm{Zn}_{1-\mathrm{x}} \mathrm{O}(\mathrm{x} \approx 0$ and 0.1 mol.\%) nanoparticles have been determined by using Ag-paste for better electrical contact and the result is shown in Fig. 6 (a, b). From these curves, DC electrical conductivity measurement of $\mathrm{Fe}_{\mathrm{x}} \mathrm{Zn}_{1-\mathrm{x}} \mathrm{O}$ ( $\mathrm{x} \approx 0$ and 0.1 mol.\%) nanoparticles taken under varying temperatures of 30, 50, 70, 90, 110 and $130{ }^{\circ} \mathrm{C}$ (Increase of 20 ${ }^{\circ} \mathrm{C}$ ). Thus, it increases the conductivity of $0.1 \mathrm{~mol} \%$ Fe-doped $\mathrm{ZnO}$ nanoparticles due to the increase in the mobility of charge carriers [44]. The remarkable increase in these samples conductivity may result in a higher advantage for optical device fabrication. 

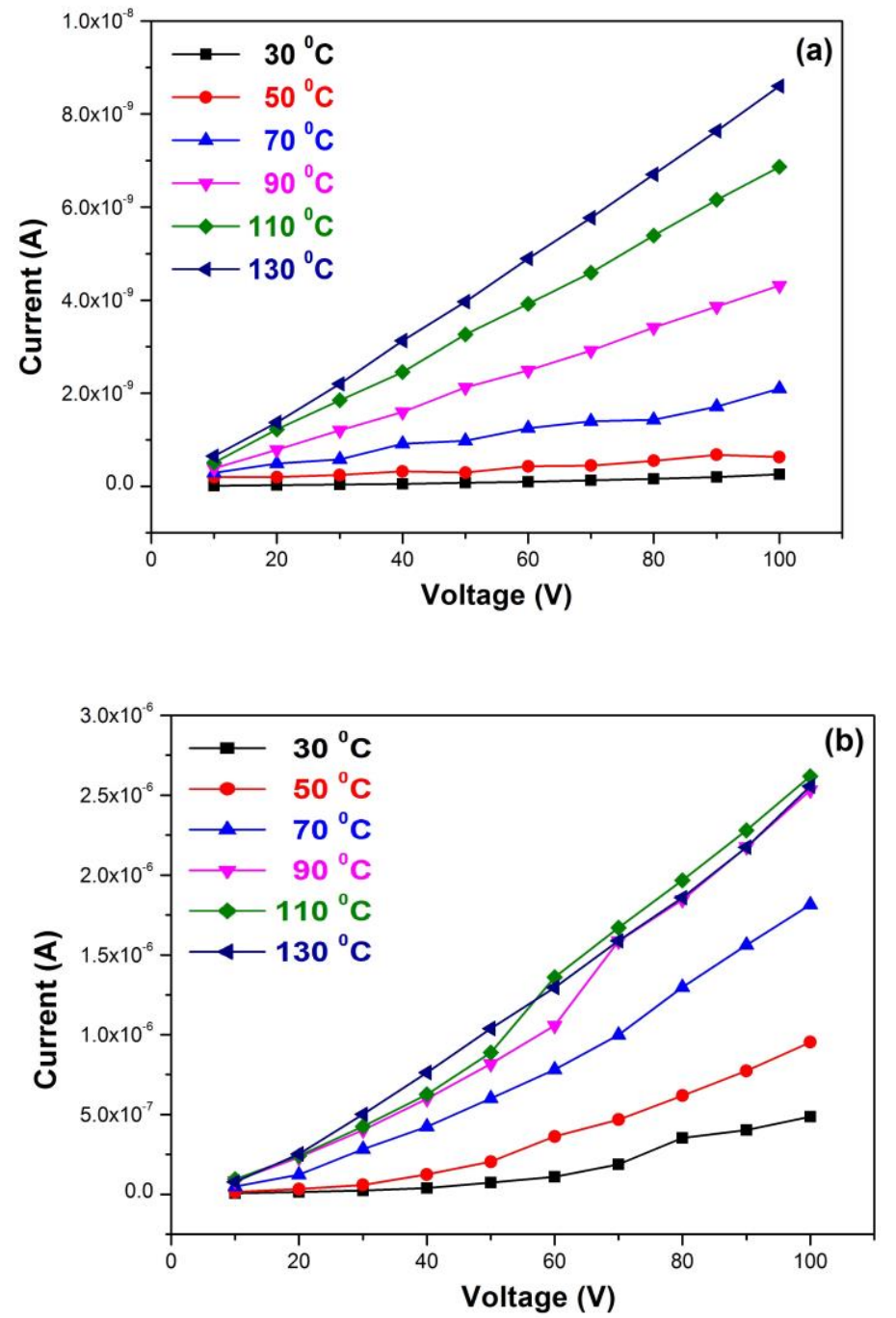

Fig. 6 I-V characteristics of (a) undoped $\mathrm{ZnO}$ and (b) 0.1 mol.\% Fe-doped $\mathrm{ZnO}$ nanoparticles.

\subsection{Photodegradation of MB and MO}

\subsubsection{Influence of pH}

The adsorption of $\mathrm{MB}$ and $\mathrm{MO}$ dye molecules on undoped $\mathrm{ZnO}$ nanoparticles strongly depends on the solution's pH displayed in Fig. 7(a). The influence of $\mathrm{pH}$ on the photodegradation of MB and MO dye was studied by varying the solution's pH from 2 to 6 . The outcome shows that photodegradation was maximum in base medium. The degradation arrives at most extreme at $\mathrm{pH}=6$ and decreases sensibly up to $\mathrm{pH}=2$. Henceforth, the $\mathrm{pH}=6$ was accepted as an ideal $\mathrm{pH}$ and utilized for additional investigation. 


\subsubsection{Influence of catalyst concentration}

The influence of catalyst concentration on the photodegradation of MB and MO dye was verified using $\mathrm{ZnO}$ catalyst concentrations from 5 to $15 \mathrm{mg} / 30 \mathrm{ml}$ in $10 \mathrm{ppm} \mathrm{MB}$, and MO dye solution at $\mathrm{pH}=6$ and it was displayed in Fig. 7(b). The variation in photodegradation can be clarified by accessibility of several surface-active sites and UV light radiation into dye solution. The photodegradation reaches maximum at $10 \mathrm{mg} / 30 \mathrm{ml}$. The reduced photodegradation at higher catalyst concentration $(15 \mathrm{mg} / 30 \mathrm{ml})$ may be due to $\mathrm{ZnO}$ nanoparticles aggregation increases the scattering effect [45]. Consequently, $10 \mathrm{mg} / 30 \mathrm{ml} \mathrm{ZnO}$ photocatalyst was expected as an ideal catalyst weight.
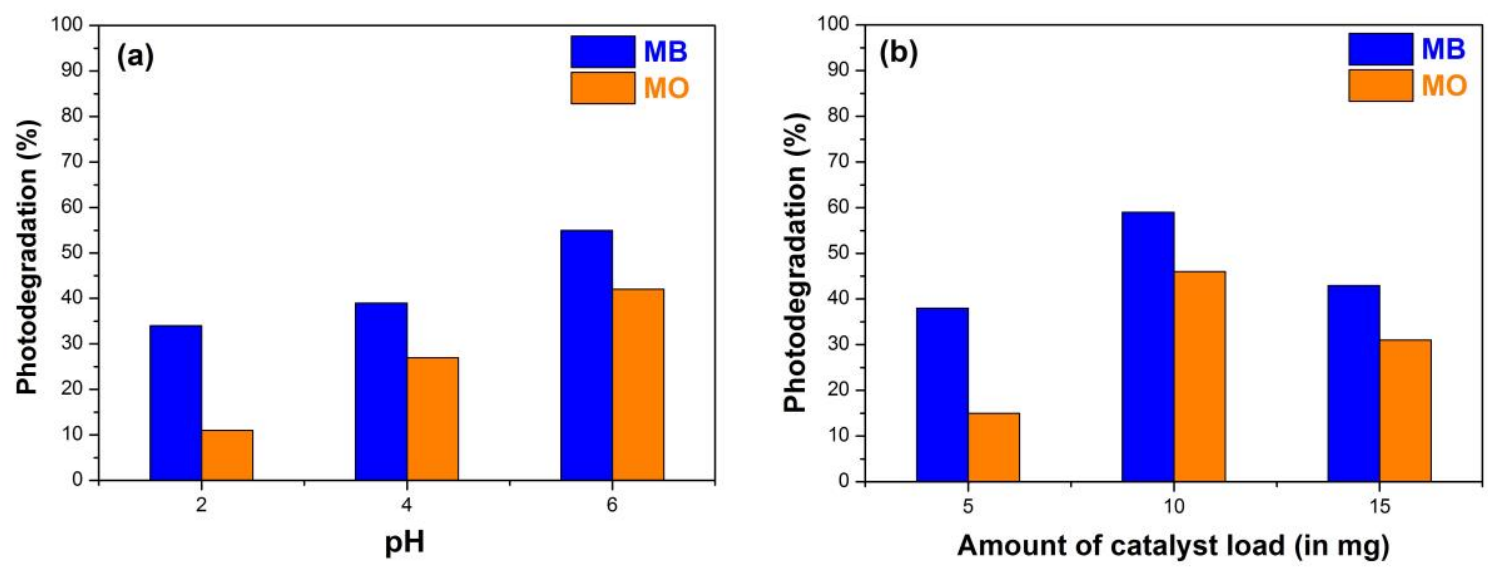

Fig. 7(a) Influence of $\mathrm{pH}$ and (b) catalyst concentration on the photodegradation of MB and MO.

\subsubsection{Influence of UV irradiation time of MB}

The photocatalytic activity was carried out with $\mathrm{MB}$ concentration of $2.0 \mathrm{mM}$, catalyst concentration of $10 \mathrm{mg}, \mathrm{pH}=6$ and irradiation time up to $150 \mathrm{~min}$. Fig. $8(\mathrm{a}-\mathrm{d})$ shows the variation in absorption spectra of MB illuminated to UV light for various irradiation times $(0,30$, $60,90,120$ and $150 \mathrm{~min})$ in the presence of $\mathrm{Fe}_{x} \mathrm{Zn}_{1-\mathrm{x}} \mathrm{O}(\mathrm{x} \approx 0,0.05,0.075,0.1 \mathrm{~mol} \%)$ nanoparticles. The intensity of absorption peaks at $664 \mathrm{~nm}$ decreases gradually with irradiation time. 
MB dye was degraded under UV light from 0 to $150 \mathrm{~min}$. in the presence of $\mathrm{Fe}_{\mathrm{x}} \mathrm{Zn}_{1-\mathrm{x}} \mathrm{O}$ $(\mathrm{x} \approx 0,0.05,0.075,0.1 \mathrm{~mol} \%)$ nanoparticles shown in Fig. 8(e). The result reveals that the Fedoped $\mathrm{ZnO}$ shows higher photocatalytic activity than that of undoped $\mathrm{ZnO}$. $\mathrm{Fe}(0.075 \%)$ doped $\mathrm{ZnO}$ shows enhanced photocatalytic activity with a degradation efficiency of $68 \%$ for $\mathrm{MB}(\mathrm{pH}=$ 6) dye at $150 \mathrm{~min}$. $\mathrm{Fe}(0.075 \%)$-doped $\mathrm{ZnO}$ nanoparticles less time to degrade the $\mathrm{MB}$ dye compared to other concentration of Fe. The reduction of photocatalytic activity at higher concentration $\mathrm{Fe}(0.1 \%)$ doped $\mathrm{ZnO}$ may be due to photons' reduced path length [45]. Similar results are also observed by Suganthi et al. [46]. Another reason for the increase in the photocatalytic activity of Fe-doped $\mathrm{ZnO}$ nanoparticles, Fe ions substituted into $\mathrm{ZnO}$ surface may suppress the electron-hole pairs recombination and enhance the dye degradation efficiency [47, 48].

\subsubsection{Influence of UV irradiation time of MO}

The photocatalytic activity was carried out with MO concentration of $3.0 \mathrm{mM}$, catalyst concentration of $10 \mathrm{mg}, \mathrm{pH}=6$ and irradiation time up to $150 \mathrm{~min}$. The variation in absorption spectra of MO showing to UV light for various irradiation times $(0,30,60,90,120$ and $150 \mathrm{~min})$ in the presence of $\mathrm{Fe}_{\mathrm{x}} \mathrm{Zn}_{1-\mathrm{x}} \mathrm{O}(\mathrm{x} \approx 0,0.05,0.075,0.1$ mol.\%) nanoparticles. The intensity of absorption peaks at $454 \mathrm{~nm}$ decreases gradually with the extension of irradiation time shown in Fig. 9(a-d).

Fig. 9(e) shows the MO dye degradation under UV light from 0 to $150 \mathrm{~min}$. in the presence of $\mathrm{Fe}_{\mathrm{x}} \mathrm{Zn}_{1-\mathrm{x}} \mathrm{O}(\mathrm{x} \approx 0,0.05,0.075,0.1 \mathrm{~mol} \%$ ) nanoparticles. The result reveals that the $\mathrm{Fe}$ $(0.075 \%)$ doped $\mathrm{ZnO}$ showed efficient photocatalytic activity with a degradation efficiency of $55 \%$ for $\mathrm{MO}(\mathrm{pH}=6)$ dye at $150 \mathrm{~min}[49]$. 

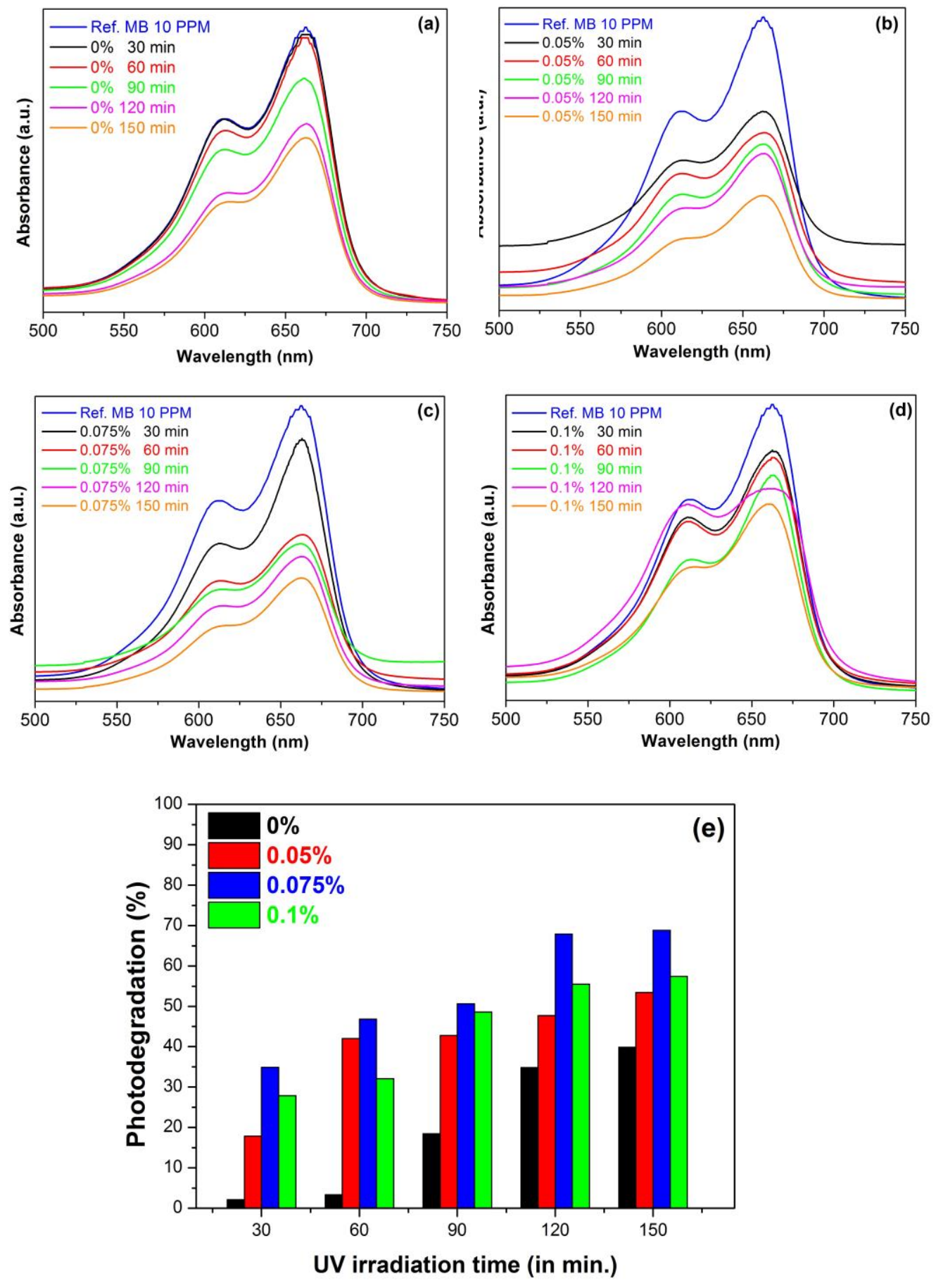

Fig. 8 UV-Vis absorption spectra of MB dye degradation of (a) undoped ZnO (b) 0.05, (c) 0.075, and (d) $0.1 \mathrm{~mol} . \% \mathrm{Fe}$-doped $\mathrm{ZnO}$ nanoparticles and (e) influence on the photodegradation of MB. 

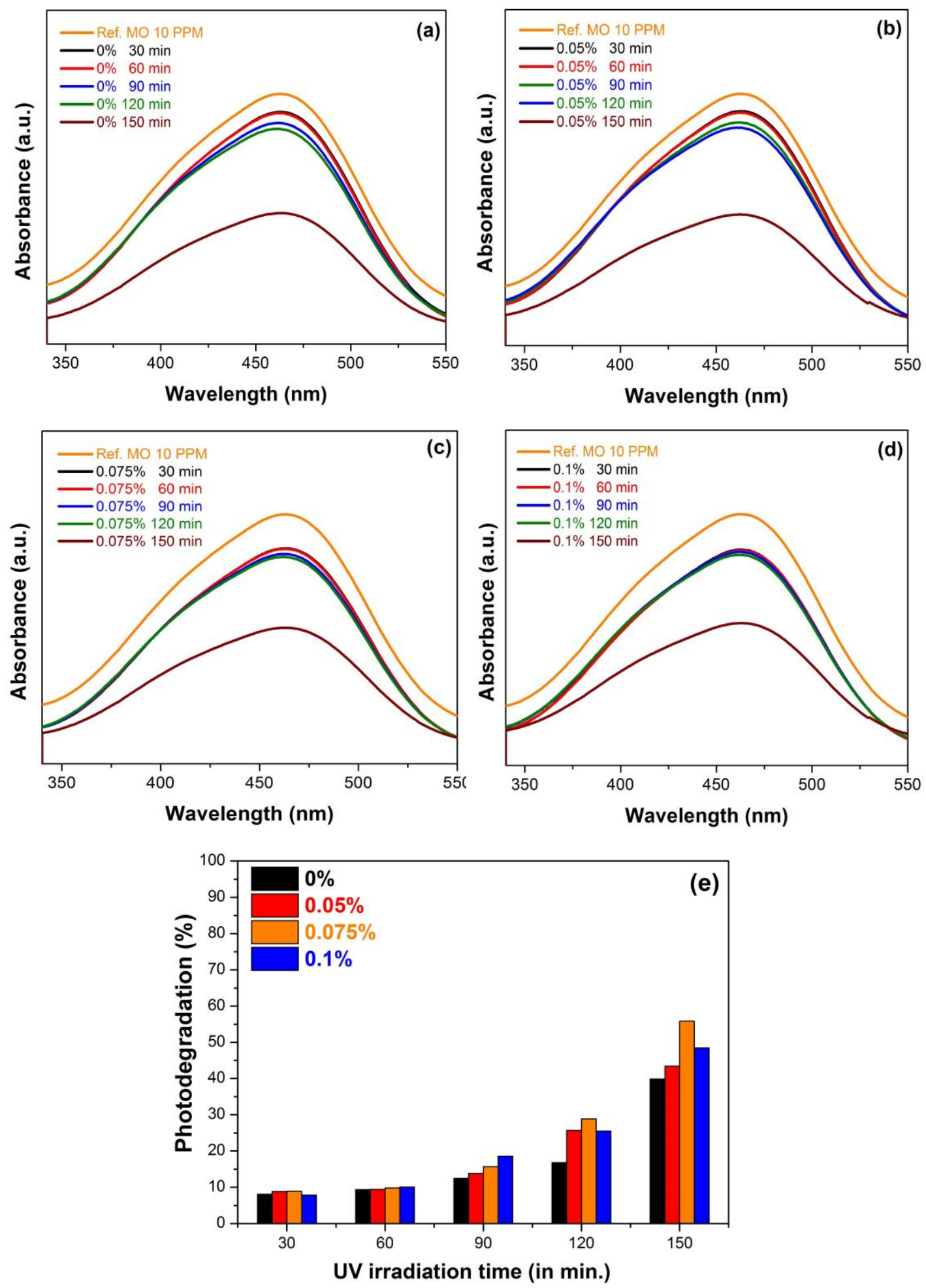

Fig. 9 UV-Vis absorption spectra of MO dye degradation of (a) undoped ZnO (b) 0.05, (c)

0.075, and (d) $0.1 \mathrm{~mol} . \%$ Fe-doped $\mathrm{ZnO}$ nanoparticles and (e) influence on the photodegradation of MO. 
In this process, narrow semiconductors act as a sensitizer to improve the dye's photodegradation based on their electronic band structure. When the photocatalyst was illuminated with higher energy photons, it only allows the dye molecule oxidation [45]. We proposed a mechanism of $\mathrm{Fe}_{\mathrm{x}} \mathrm{Zn}_{1-\mathrm{x}} \mathrm{O}$ nanoparticles for efficient photocatalytic activity. It can be described as follows:

$$
\begin{aligned}
\mathrm{ZnO}+\mathrm{h} \gamma & \longrightarrow \mathrm{ZnO}\left(\mathrm{h}^{+} \mathrm{VB}+\mathrm{e}^{-} \mathrm{CB}\right) \\
\left(\mathrm{h}^{+} \mathrm{VB}\right)+\text { dye } & \longrightarrow \text { dye }^{+} \mathrm{VB}
\end{aligned}
$$

When $\mathrm{ZnO}$ is illuminated by visible light, holes $\left(\mathrm{h}^{+} \mathrm{vB}\right)$ and electrons $\left(\mathrm{e}^{-} \mathrm{CB}\right)$ are generated and passed through from valence to conduction band. The photogenerated electrons and holes combine with $\mathrm{Fe}^{3+}$ ions, respectively.

$$
\begin{aligned}
& \mathrm{Fe}^{3+}+\mathrm{O}_{2} \longrightarrow \mathrm{Fe}^{5+}+\mathrm{O}_{2}{ }^{\circ}-\text { (electron release) } \\
& \mathrm{Fe}^{3+}+\mathrm{OH}^{-} \longrightarrow \mathrm{Fe}^{2+}+\mathrm{OH}^{\circ} \text { (hole release) } \\
& \mathrm{OH}^{\circ}+\text { dye }(\mathrm{MB} \& \mathrm{MO}) \longrightarrow \text { oxidation of dye molecule }
\end{aligned}
$$

These superoxide anions $\left(\mathrm{O}_{2}{ }^{\circ}-\right)$ and hydroxyl radicals $\left(\mathrm{OH}^{\circ}\right)$ are strong oxidizing species, and it will degrade of MB and MO dye molecule (Eq. 7) [49]. From these results, novel Fedoped $\mathrm{ZnO}$ nanoparticles have played a primary role in the degradation of organic dyes from wastewater.

\section{Conclusion}

In this paper, we reported the synthesis of $\mathrm{Fe}_{\mathrm{x}} \mathrm{Zn}_{1-\mathrm{x}} \mathrm{O}(\mathrm{x} \approx 0,0.05,0.075 \& 0.1 \mathrm{~mol} . \%)$ nanoparticles by co-precipitation method. The intensity of Fe-doped $\mathrm{ZnO}$ nanoparticles decreases due to the incorporation of Fe $(0.05,0.075 \& 0.1 \mathrm{~mol} \%)$, confirmed by XRD. Doping of Fe modifies the morphology and crystallite size of $\mathrm{ZnO}$ nanoparticles and it was estimated to be $\sim 42-68 \mathrm{~nm}$. UV-Vis absorbance studies reveals that increasing of Fe concentration up to 0.1 mol.\%, the band gap decreases when compared with undoped $\mathrm{ZnO}$. The maximum percentage of $\mathrm{MB}$ and MO photodegradation was achieved for the dosage concentration of $10 \mathrm{mg}$ and irradiation time of $150 \mathrm{~min}$ at $\mathrm{pH}=6$. Fe-doped $\mathrm{ZnO}$ nanoparticles may be used as an efficient photocatalyst to degrade the organic dyes under UV light. 


\section{References}

1. A. Nezamzadeh-Ejhieh, N. Moazzeni, J. Ind. Eng. Chem. 19 (2013) 1433.

2. M. Safari, M. Nikazar, M. Dadvar, J. Ind. Eng. Chem. 19 (2013) 1697.

3. A. Arques, A.M. Amat, A. Garcia-Ripoll \& R. Vicente, J. Hazard. Mater. 146 (2007) 447.

4. V.K. Gupta, D. Pathania, S. Agarwal, P. Singh, J. Hazard. Mater. 243(179) (2012).

5. B.K. Korbahti, K. Artut, C. Gecgel \& A. Ozer, Chem. Eng. J. 173(677) (2011).

6. J.B. Joo et al. Adv. Funct. Mater. 23(4246) (2013).

7. T.H. Yu, W.Y. Cheng, K.J. Chao \& S.Y. Lu, Nanoscale 5(7356) (2013).

8. M. Lima, D. Fernandes, M. Silva, M. Baesso, A. Neto, G. de Morais, et al., J. Sol-Gel Sci.Technol.72(2014)301-309.

9. B. Cao \& W. Cai, J. Phys. Chem. C 112(680) (2008).

10. R. Saravanan, et al. RSC Adv 5(34645) (2015).

11. R. Saravanan, et al. Materials Science and Engineering C 33(2235) (2013).

12. S.Y. Lee, S.J. Park, J. Ind. Eng. Chem. 19 (2013) 1761.

13. S. Liu, C. Li, J. Yu, Q. Xiang, Cryst Eng Comm 13 (2011) 2533.

14. D. Rajesh, B. Varalakshmi, C.S. Sunandana, Phys. B 407 (2012) 4537e4539.

15. M. Arshad, M.M. Ansari, A.S. Ahmed, P. Tripathi, S.S.Z. Ashraf, A.H. Naqvi, A. Azam, J. Lumin. 161 (2015) 275e280.

16. L. Chow, O. Lupan, G. Chai, H. Khallaf, L.K. Ono, B.R. Cuenya, I.M. Tiginyan, V.V. Ursaki, V. Sontea, A. Schulte, Sens. Actuators A 189 (2013) 399e408.

17. Y.X. Liua, Y.C. Liua, D.Z. Shena, G.Z. Zhonga, X.W. Fana, X.G. Konga, R. Muc, D.O. Hendersonc, J. Cryst. Growth 240 (2002) 152e156.

18. T. Bak, J. Nowotny, M. Rekas, C. Sorrell, Int. J. Hydr. Energy 27, 991-1022 (2002)

19. Z. Han, L. Ren, Z. Cui, C. Chen, H. Pan, J. Chen, Appl. Catal. B: Environ. 126 (2012) 298.

20. S.S. Shinde, C.H. Bhosale, K.Y. Rajundoped, J. Photochem. Photobiol. B 113 (2012) 70.

21. Y. Min, K. Zhang, Y. Chen, Y. Zhang, W. Zhao, Sep. Purif. Technol. 92 (2012) 115.

22. A. Moulahi, F.Sediri, Ceram. Int. 40(2014)943-950.

23. N.L. Tarwal, P.R.Jadhav, S.A.Vanalakar, S.S.Kalagi, R.C.Pawar, J.S.Shaikh, et al., Powder Technol. 208(2011)185-188.

24. T.Ivanova, A.Harizanova, T.Koutzarova, B.Vertruyen, Mater.Lett.64(2010)1147-1149. 
25. A. Rahmati, A.B. Sirgani, M.Molaei, M.Karimipour, Eur. Phys. J. Plus 129 (2014) 7.

26. P. Malathy, K. Vignesh, M. Rajarajan, A. Suganthi, Ceram. Int. 40 (2014) 101.

27. B.M. Rajbongshi, S.K. Samdarshi, Appl. Catal. B: Environ. 144 (2014) 435.

28. S. Dong, K. Xu, J. Liu, \& H. Cui, Physica B 406(3609) (2011).

29. Y. Zhang, M.K. Ram, E.K. Stefanalkos, \& D.Y. Goswami, Surf. Coat. Technol. 217(119) (2013).

30. M.M. Ba-Abbad, A.A.H. Kadhum, A. Mohamad, M.S. Takriff, K. Sopian, Chemosphere, 91 (2013) 1604-1611.

31. A.A. Ashkarran, A. Irajizad, S.M. Mahdavi, M.M. Ahadian, Mater. Chem. Phys.118 (2009) 6-8.

32. J. Zhou, F. Zhao, Y. Wang, Y. Zhang, and L. Yang, J. Lumin. 122-123 (2007) 195-197.

33. S. Bai, T.Guo, Y.Zhao, SunJ, D.Li, A.Chen, et al., Sens. Actuators B: Chem.195 (2014) 657666.

34. M. Nasir, S. Bagwasi, Y. Jiao, F. Chen, B. Tian, J. Zhang, Chem. Eng. J. 236 (2014) 388.

35. R. Jeyachitra, V. Senthilnathan, T.S.Senthil, J Mater Sci: Mater Electron, 29 (2018) 11891197.

36. G. Srinivasan, J. Kumar, Cryst. Growth 310, 1841 (2008)

37. C.W. Nahm, J. Mater. Sci. Mater. Electron. 24, 70 (2013)

38. R. Viswanatha, Y.A. Nayaka, C.C. Vidyasagar, T.G. Venkatesh, J. Chem. Pharm. Res. 4 (4) (2012) $1983 \mathrm{e} 1989$.

39. C.C. Vidyasagar, Y.A. Naik, T.G. Venkatesh, R. Viswanatha, Powder Technol. 214 (2011) $337 \mathrm{e} 343$.

40. T.G. Venkatesh, Y.A. Nayaka, R. Viswanatha, C.C. Vidyasagar, B.K. Chethana, Power Tech. 225 (2012) 232-238.

41. M.M. Hassan, W. Khan, A. Azam, A.H. Naqvi, J. Ind. Eng. Chem. 21 (2015) 283-291.

42. Amalia Mesaros, Cristina D. Ghitulica, Mihaela Popa, Raluca Mereu, Adriana Popa, Traian Petrisor Jr., Mihai Gabor, Adrian Ionut Cadis, Bogdan S. Vasile, Ceram. Int. 40 (2014) 2835-2846.

43. C. Liu, D. Meng, H. Pang, X. Wua, J. Xie, X. Yu, L. Chen, X. Liu, J. Magn. Magn. Mater. 324, 3356 (2012). 
44. S. Abed, H. Bougharraf, K. Bouchouit, Z. Sofiani, B. Derkowska-Zielinska, M.S. Aida, B. Sahraoui, Superlattice Microstruct. 85,370 (2015)

45. S.V. Elangovan, V. Chandramohan, N. Sivakumar \& T.S. Senthil, Desalination and Water Treatment, 57 (2016) 9671-9678.

46. K. Vignesh, M. Rajarajan, A. Suganthi, Journal of Industrial and Engineering Chemistry, 20 (2014) 3826-3833.

47. W. Bousslama, H. Elhouichet, M. Ferid, Optik 134 (2017) 88

48. X. Yu, D. Meng, C.Li.U.K. Xu, J. Chen, C. Lu, Y. Wang, J. Mater. Sci. 25 (2014) 3920

49. S.K. Kansal, M. Singh, D. Sud, J. Hazard. Mater. 141 (2007) 581-590. 
Figures
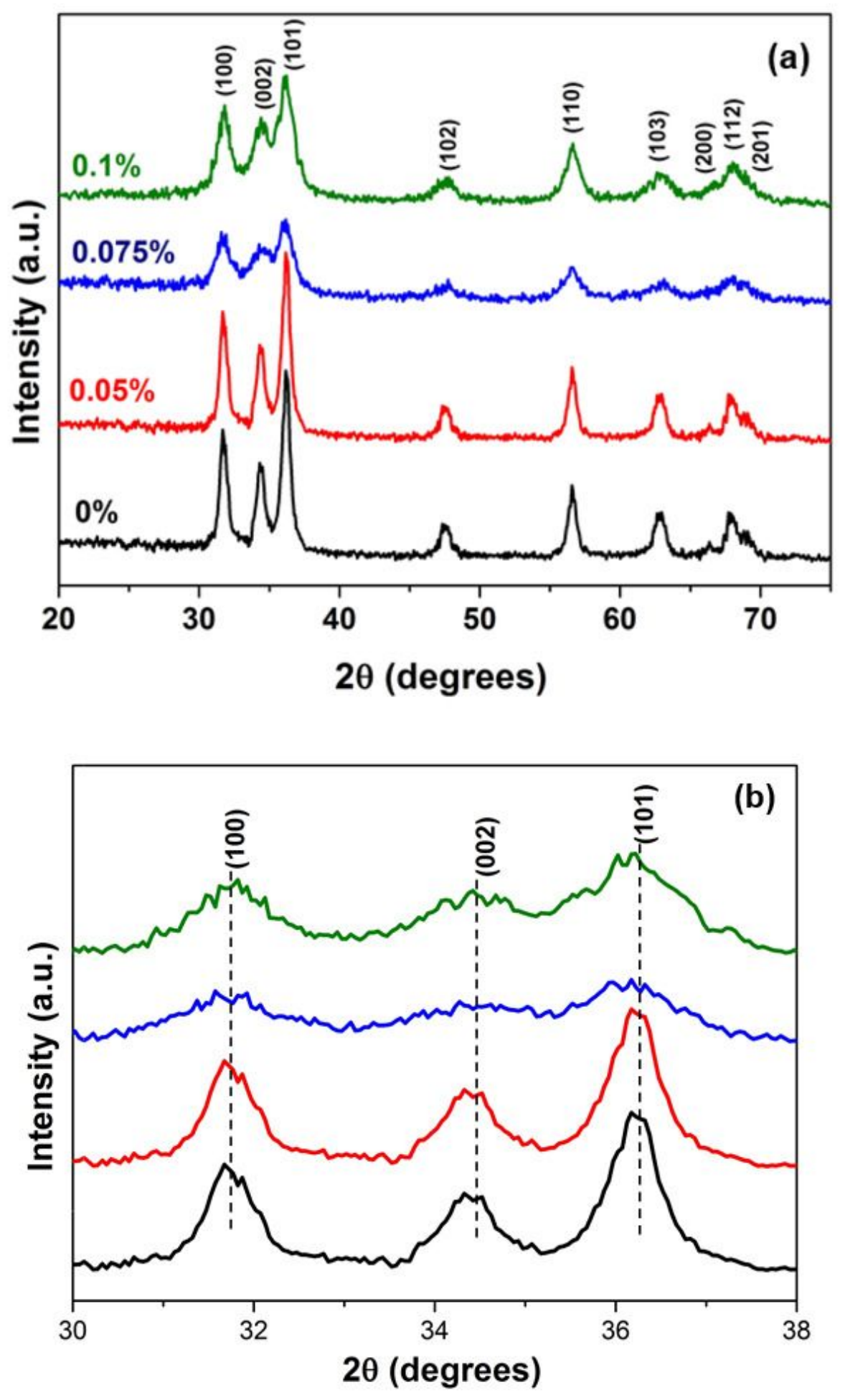

Figure 1

(a) XRD patterns of (a) undoped $\mathrm{ZnO}$ and Fe-doped $\mathrm{ZnO}(0.05,0.075 \& 0.1$ mol.\%) nanoparticles (b) Fe concentration dependent shift in primary diffraction peaks. 

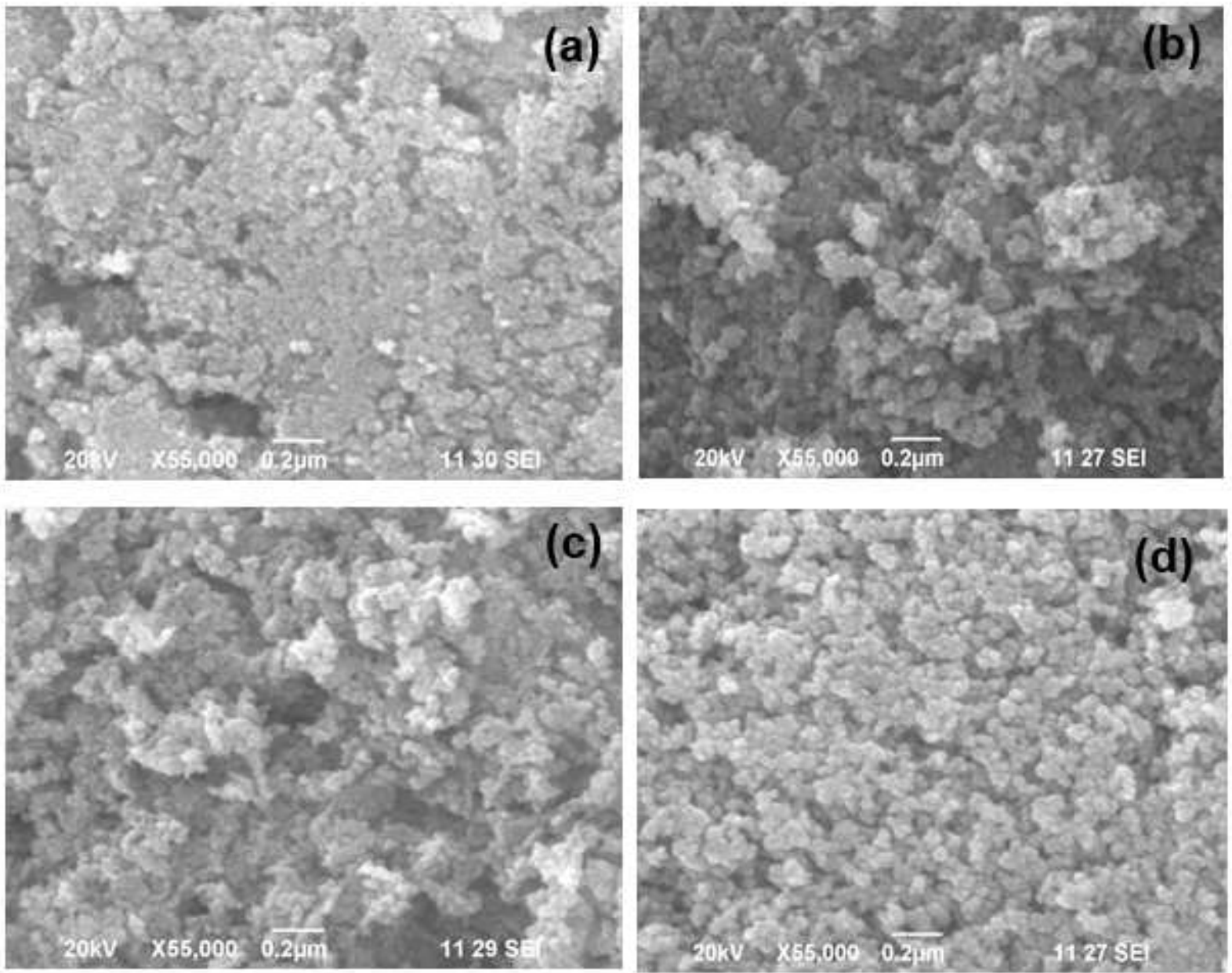

\section{Figure 2}

SEM images of (a) undoped ZnO (b) 0.05, (c) 0.075 and (d) 0.1 mol.\% Fe-doped ZnO nanoparticles 

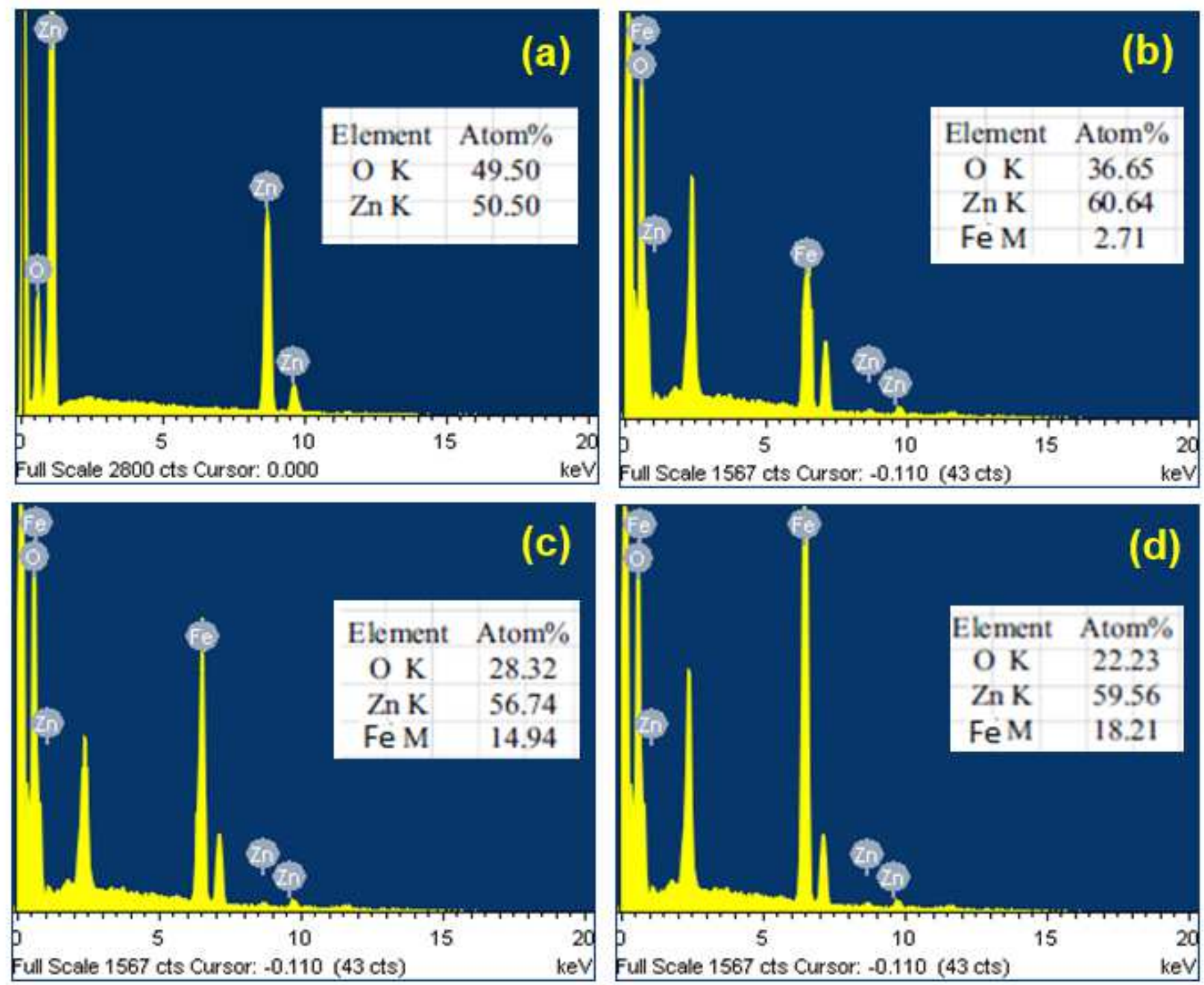

Figure 3

EDS images of (a) undoped ZnO (b) 0.05, (c) 0.075 and (d) 0.1 mol.\% Fe-doped ZnO nanoparticles 


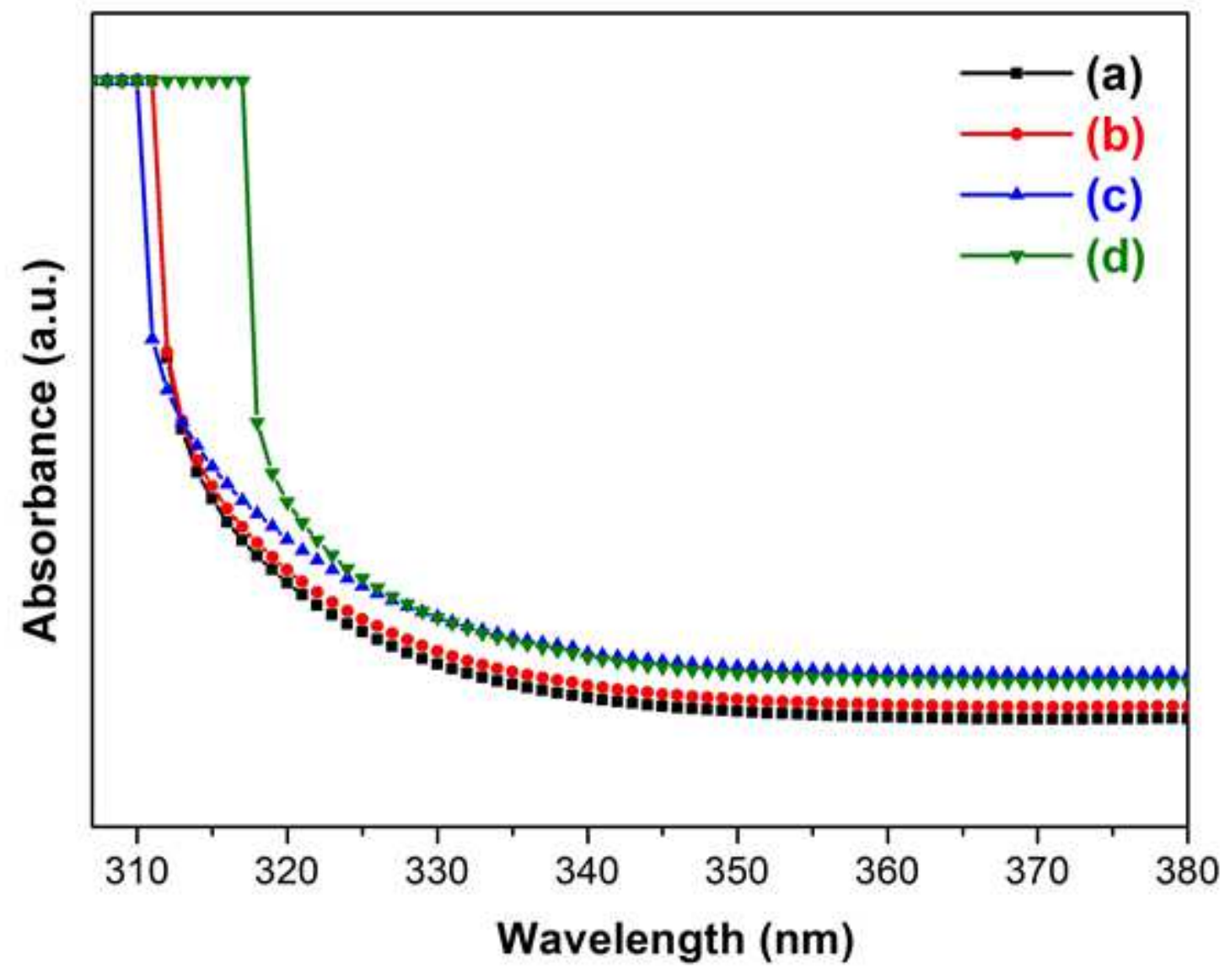

Figure 4

UV-Vis absorbance spectra of (a) undoped ZnO (b) 0.05 , (c) 0.075 and (d) 0.1 mol.\% Fe-doped ZnO nanoparticles 


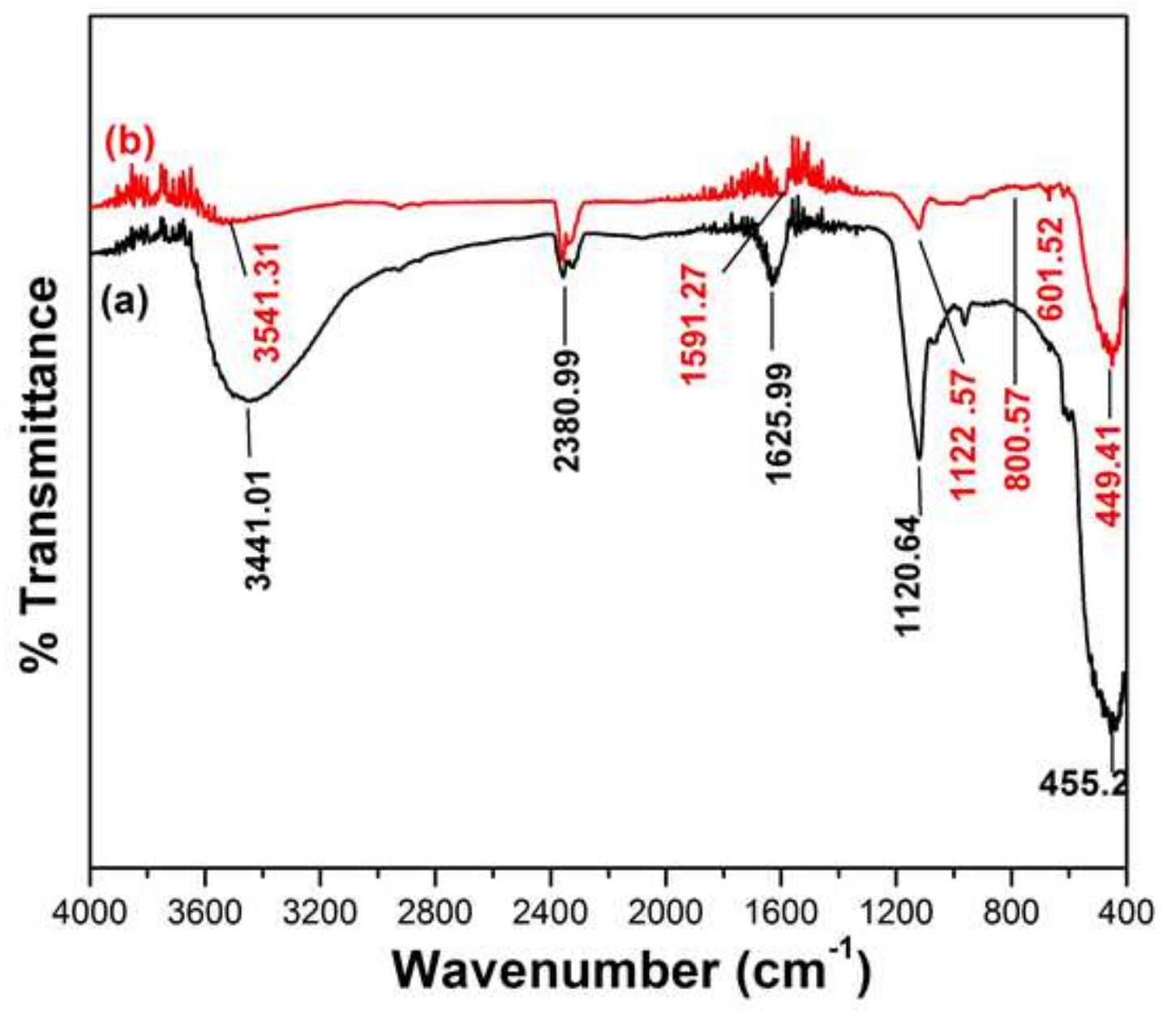

Figure 5

FT-IR spectra of (a) undoped ZnO and (b) 0.1 mol.\% Fe-doped ZnO nanoparticles 

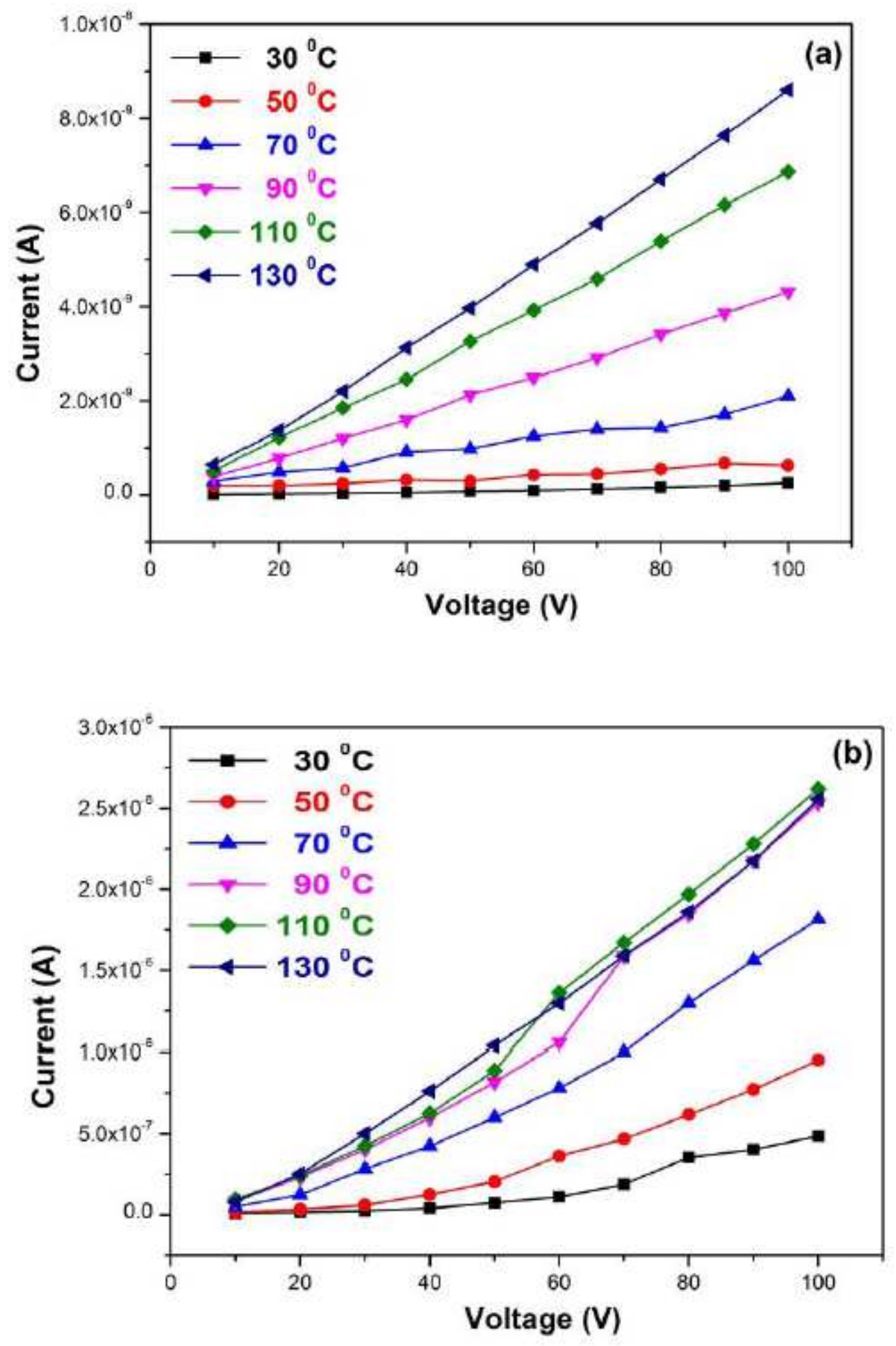

Figure 6

I-V characteristics of (a) undoped $\mathrm{ZnO}$ and (b) 0.1 mol.\% Fe-doped $\mathrm{ZnO}$ nanoparticles. 

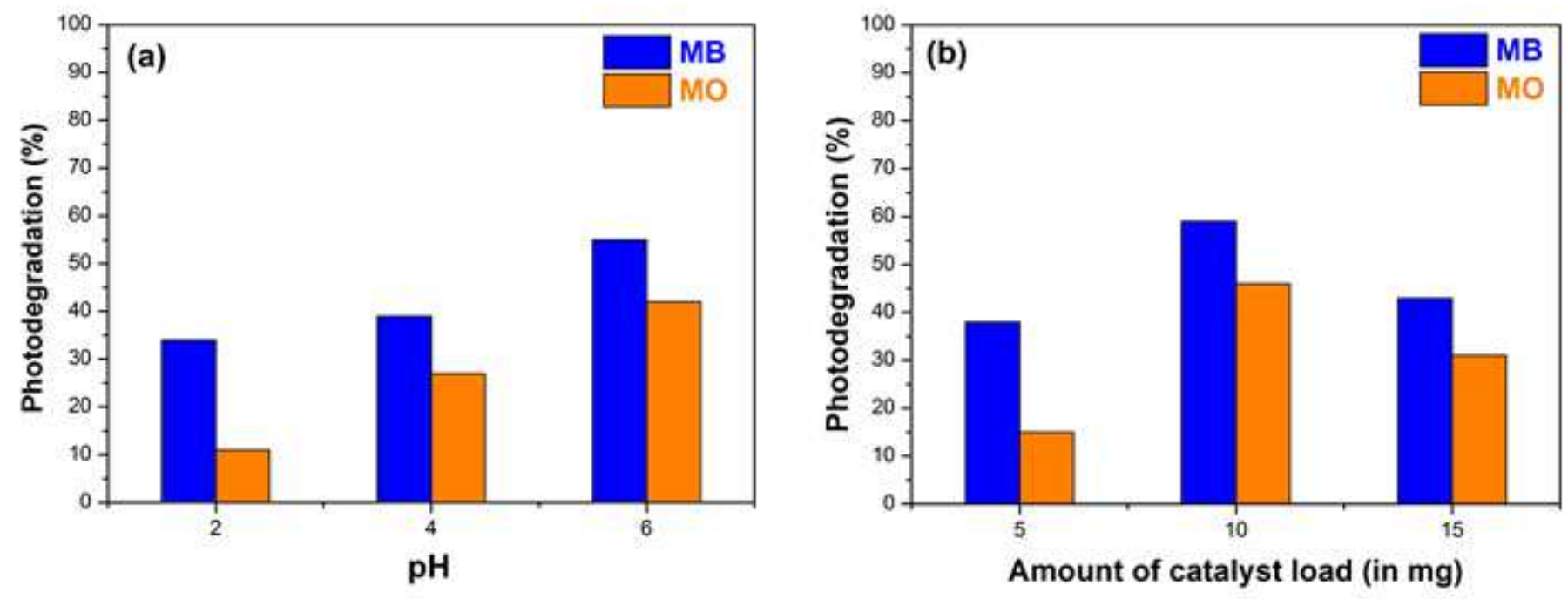

Figure 7

(a) Influence of $\mathrm{pH}$ and (b) catalyst concentration on the photodegradation of MB and MO. 

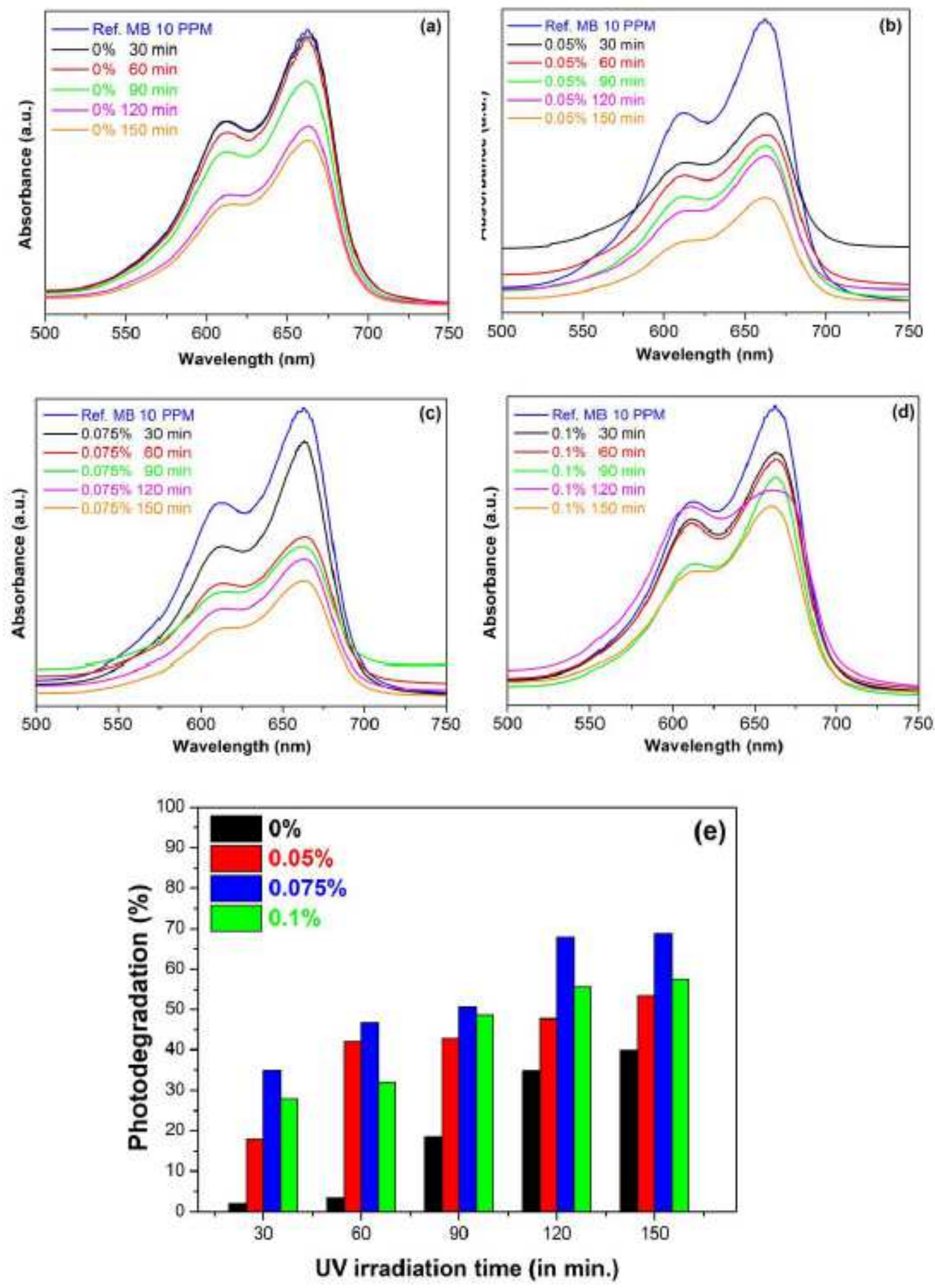

\section{Figure 8}

UV-Vis absorption spectra of MB dye degradation of (a) undoped $\mathrm{ZnO}$ (b) 0.05 , (c) 0.075 , and (d) 0.1 mol.\% Fe-doped ZnO nanoparticles and (e) influence on the photodegradation of MB. 

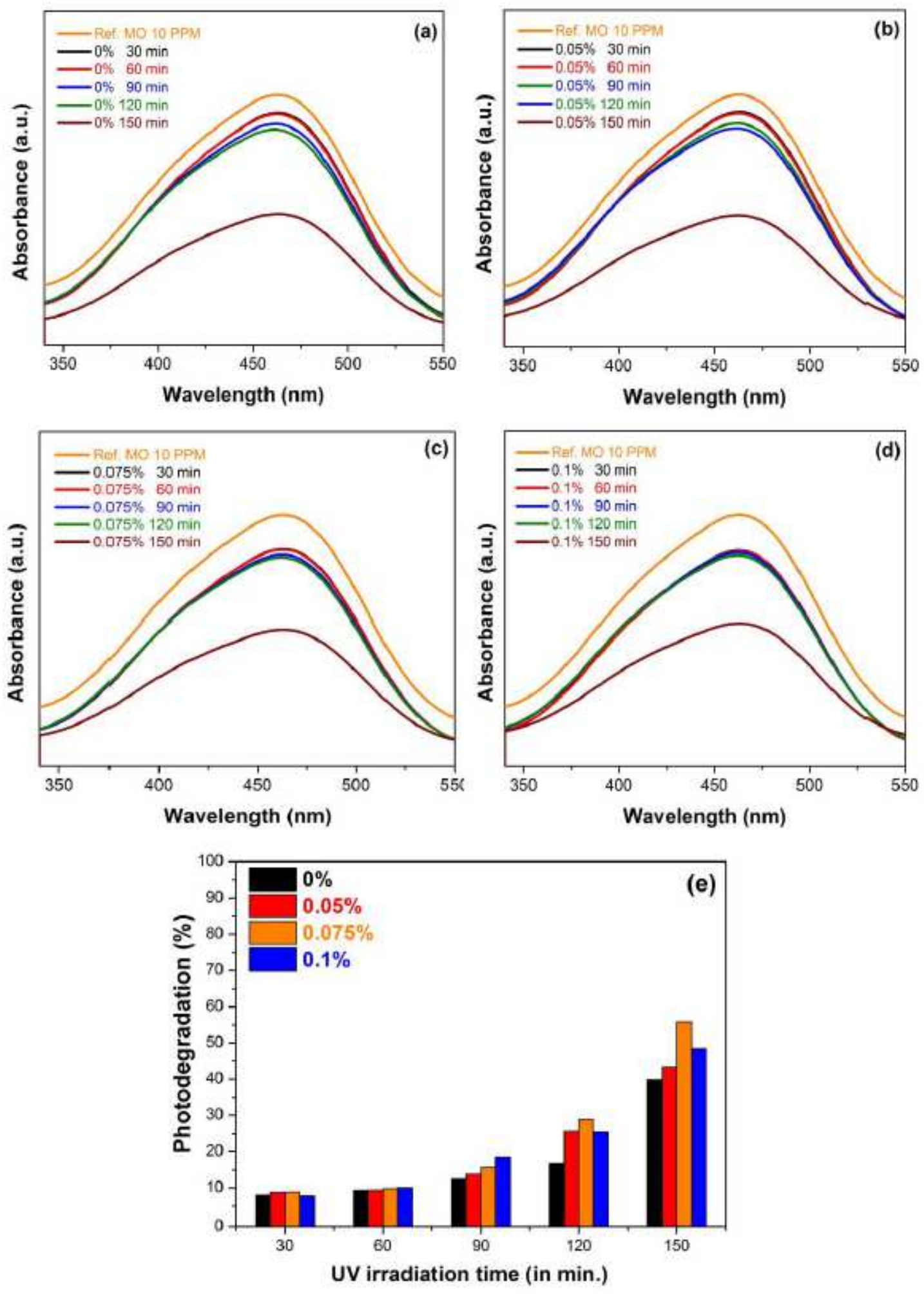

\section{Figure 9}

UV-Vis absorption spectra of $\mathrm{MO}$ dye degradation of (a) undoped $\mathrm{ZnO}$ (b) 0.05 , (c) 0.075 , and (d) 0.1 mol.\% Fe-doped ZnO nanoparticles and (e) influence on the photodegradation of MO. 